\title{
COLLECTIVE GOODS, MOBILE RESOURCES, AND EXTRATERRITORIAL TRADE CONTROLS
}

\author{
KenNeth W. AbBotT*
}

\section{INTRODUCTION}

In 1981-82, the United States imposed a set of far-reaching extraterritorial restraints on sales of oil and gas transmission equipment and technology to the Soviet Union in an effort to prevent or delay completion of the Yamal natural gas pipeline. ${ }^{1}$ This action touched off the most violent dispute over extraterritoriality in the history of American trade controls. ${ }^{2}$ Since that time, numerous law review articles ${ }^{3}$ and speeches, ${ }^{4}$ a few legal briefs, ${ }^{5}$ and even a

Copyright $\odot 1988$ by Law and Contemporary Problems

* Professor of Law, Northwestern University School of Law.

1. The most controversial controls were imposed in June 1982. See 47 Fed. Reg. 27,250 (1982) (to be codified at 15 C.F.R. $\$ \S 376,379,385$ ). A more limited set of controls had been imposed in December 1981. See 47 Fed. Reg. 141 (1982) (to be codified at 15 C.F.R. $\S \S 379,385,399$ ). For a description of the two sets of controls, see Abbott, Defining the Extraterritorial Reach of American Export Controls: Congress as Catalyst, 17 CORNELL. INT'L L.J. 79, 82-87 (1984).

2. For detailed summaries of the pipeline episode, see Abbott, supra note 1 , at $82-90 ; 3 \mathrm{~A}$. Lowenfeld, International Economic Law, Trade Controls for Political Ends, ch. II, \$\$ 5.4-5.6 (2d ed. 1983) [hereinafter A. Lowenfeld, International Economic Law]; Moyer \& Mabry, Export Controls as Instruments of Foreign Policy: The History, Legal Issues, and Policy Lessons of Three Recent Cases, 15 LAW \& POL'y INT'L Bus. 1, 60-9l (1983).

3. See, e.g., Abbott, supra note 1, at 82-90; Moyer \& Mabry, supra note 2, at 60-91; Butler, The Extraterritorial Reach of the United States Export Administration Act, 1983 J. Bus. L. 275; Bridge, The Law and Politics of United States Foreign Policy Export Controls, 4 Legal Stud. 2 (1984); Ellicott, Extratemitorial Trade Controls-Law, Policy and Business, in Private Investors Abroad-Problems and Solutions in International Business in 1983 (1984); Lowe, Public Intermational Lau and the Confict of Laues: The European Response to the United States Export Administration Regulations, 33 INT'L \& CoMP. L.Q. 515 (1984); Morse \& Powers, U.S. Export Controls and Foreign Entities: The Lnansuered Questions of Pipeline Diplomacy, 23 VA. J. INT'L L. 537 (1983); Note, Extraterritorial Application of the Export Admimistration .Act of 1979 linder International and American Law, 81 Mich. L. REv. 1308 (1983); Note, Extraterritorial Application of United States Law: The Case of Export Controls, 132 U. PA. L. Rev. 355 (1984); Perlow, Taking Peacetime Trade Sanctions to the Limit: The Soviet Pipeline Embargo, 15 CASE W. RES. J. INT'L L. 253 (1983).

4. See, e.g., Dam, Extraterritoriality, Conflicts of Jurisdiction, and L'nited States Foreign Policy. Address to American Society of International Law (Apr. 15, 1983); Havers, Good Fences . Iade Good Ieighbors: At Discussion of Problems Concerning the Exercise of Jurisdiction, Address to American Bar Ass' $\mathrm{n}$, Section of Int'l Law and Practice (Aug. 2, 1983), reprinted in 17 INr'L L. 784 (1983); Secretary of State Shultz. Trade, Interdependence, and Conficts of Jurisdiction, Address to South Carolina Bar Ass'n (May 5, 1984), reprinted in 84 DEP'T ST. BULl., June 1984, at 33.

5. See, e.g., Motion to Vacate Temporary Denial of Export Privileges and Memorandum in Support. In ie Dresser, No. 632 (U.S. Department of Commerce, International Trade Administration, Aug. 27, 1982); Post-Hearing Brief of U.S. Department of Commerce, In re Dresser, No. 632 (U.S. Department of Commerce, International Trade Administration 1982); Motion to Vacate Order Temporarily Denying Export Privileges and Memorandum in Support, In re John Brown Engineering 
judicial opinion ${ }^{6}$ have discussed what the Attorney-General of the United Kingdom called the "pipeline fiasco."7

Most of these writings deal with the extraterritoriality issue by testing the validity of the American controls against what are presented as the accepted rules of international law regarding national prescriptive jurisdiction. ${ }^{8}$ These rules are applied either directly or as constraints on the interpretation of the Export Administration Act (EAA), ${ }^{9}$ the statute under which the controls were imposed. ${ }^{10}$ Some writings discuss the "reasonableness" principle set forth in section 403 of the Restatement (Revised) of Foreign Relations Law, ${ }^{11}$ or its predecessor, the "comity" principle expressed in section 40 of the Restatement (Second) of Foreign Relations Law, ${ }^{12}$ as a limit on extraterritorial controls. ${ }^{13}$ The predominant approach, however, is to focus on the "minimum bases of jurisdiction to prescribe law"14-territoriality, nationality, and, to a lesser extent, the protective principle-set out in section 402 of the Restatement (Revised), as the principles of law by which the validity of the pipeline regulations should and can be judged. ${ }^{15}$

Limited, No. 635 (U.S. Department of Commerce, International Trade Administration Oct. 1, 1982); European Communities, Comments on the U.S. Regulations Concerning Trade with the U.S.S.R., reprinted in 21 INT'L Legal Mat. 891.904 (1982) [hereinafter EC Comments].

6. Compagnie Europeene de Petroles v. Sensor Nederland, No. 82/716 (Dist. Ct., the Hague, Sept. 13, 1984), reprinted in 22 INT'L Legal MAT. 66 (1983).

7. See Havers, Good Fences Make Good Neighbors, supra note 4, at 24.

8. See, e.g., Butler, supra note 3, at 280-82; Bridge, supra note 3, at 7-17; Morse \& Powers, supra note 3, at 557-67; Note, Extraterritorial Application of EAA, supra note 3, at 1315-34; Note, Extraterritorial Application of United States Law, supra note 3, at 366-89; Perlow, supra note 3, at 267-77; Dresser Memorandum, supra note 5, at 70-87; John Brown Memorandum, supra note 5, at 23-29; Brief of U.S. Department of Commerce, supra note 5, at 44-51. See also Marcuss \& Richard, Extrateritorial Jurisdiction in United States Trade Law: The Need for a Consistent Theory, 20 Colum. J. Transnat'L L. 439 (1981); Feldman, The Restructuring of National Security Controls under the 1985 . Amendments to the Export Administration Act: Multilateral Diplomacy and the Extraterritorial Application of Lnited States Lau, 21 STAN. J. INT'L L. 235 (1985).

9. Export Administration Act of 1979, Pub. L. No. 96-72, 93 Stat. 503 (codified as amended at 50 U.S.C. $\$ \$ 2401-20$ (1982)). The pipeline controls were imposed under the foreign policy section of the EAA, 50 U.S.C. $\$ 2405$ (1982).

10. Aside from procedural due process, the principal argument made by the firms sanctioned for non-compliance with the pipeline controls in their legal actions challenging the temporary denial orders imposed against them was that the 1982 regulations exceeded the President's authority under the EAA, in that the statute must be construed consistently with international law, if at all possible, and the regulations were contrary to international law. See Ellicott, supra note 3, at 22-26.

Many of the articles cited in note 3 also consider arguments that the controls went beyond the congressional intent as to the extraterritorial reach of the EAA. See. e.g., Morse \& Powers, supra note 3, at 544-56; Note, Extraterritorial Application of the EAt, supra note 3, at $1311-14$; Pcrlow, supra note 3, at $258-67$.

11. Restatement (Revised) of Foreign Relations Law of the United States $\S 403$ (Tent. Draft No. 7, 1984) [hereinafter Restatement (Revised) Draft No. 7].

12. Restatement (Second) of Foreign Relations Law of the United States $\$ 40$ (1965) [hereinafter RESTATEMENT (SECOND)].

13. See, e.g., Morse \& Powers, supra note 3, at 564-67; Note, Extratemitorial Application of the E.t.t, supra note 3, at 1331-34, EC Comments, supra note 5, at 893-903.

14. Restatement (Revised) of Foreign Relations Law of the United States $§ 402$ comment a (Tent. Draft. No. 6, 1985) [hereinafter Rfstatement (Revised) Draft No. 6].

15. Id. $\S 402$. 
The "minimum bases" approach may be appropriate for briefs and judicial decisions, ${ }^{16}$ but it is somewhat unsatifying in a scholarly article. ${ }^{17}$ First, such a positivistic approach does not reveal the sources of the extraterritoriality dispute or its unusual intensity and persistence, and thus does not suggest ways of resolving it. Second, this approach invokes, as if they were unambiguous and clearly controlling, rules that are by no means clear, ${ }^{18}$ that are unlikely to receive an authoritative interpretation, that are not unanimously accepted as binding, ${ }^{19}$ and that have proven themselves unable to resolve either the continuing controversy or the 1982 crisis.

This article will look at the extraterritoriality issue more broadly. The perspective of the article is based in part on modern international relations theory, ${ }^{20}$ which, like much legal scholarship, has been strongly influenced by economics. ${ }^{21}$ Using this approach, the article will identify two general problems in international politics-what might be called structural problems of the international system-that are important in understanding the positions of the two sides in the extraterritoriality controversy, their emotional commitment to these positions, and even their legal arguments.

After considering these problems, the article will detail the inadequacies of international legal doctrines currently available for dealing with themprimarily the rules on national prescriptive jurisdiction, but also certain other principles of international law cited during the pipeline controversy. In the process, the article will present some arguments favorable to the U.S. position on extraterritorial trade controls, arguments rarely advanced in other scholarly commentary. The article will then briefly review some post-1982 developments, suggest what the future may hold, and conclude with some recommendations for defusing the extraterritoriality controversy. Because the 1981-82 pipeline controls constitute the background against which discussions of the issue must proceed, this article will begin by briefly reviewing the coverage of those controls.

\section{II}

\section{The 1981-82 Pipeline Controls}

The extraterritorial aspects of the pipeline controls can be divided into two groups. First, the United States prohibited exports of controlled items to

16. See briefs and comments cited supra note 5; Sensor Nederland, supra note 6 .

17. Admittedly, the same criticism can be levelled at one of this author's own efforts in this field. See Abbott, Linking Trade to Political Goals: Foreign Policy Export Controls in the 1970s and 1980s, 65 MinN. L. Rev. 739, 842-43 (1981) [hereinafter Abbott, Linking Trade].

18. See infra text accompanying notes $143-83$

19. See infra text accompanying notes $118-42$

20. For a brief discussion of the types of theory on which I have principally relied, see Keohane, Theon of World Politics: Structural Realism and Beyond, in Polmtical Science: The State of the Discipline 503, 528-32 (A. Finifter ed. 1983).

21. This author is currently at work on an article, tentatively entitled The Yodern Theory of International Relations and International Law, that reviews this theory and examines its relevance to international legal problems. 
the Soviet Union by foreign subsidiaries and affiliates of American firms. ${ }^{22}$ Transactions by foreign subsidiaries had previously been restricted by the Foreign Assets Control Regulations and other control programs instituted under U.S. emergency legislation. ${ }^{23}$ This was the first time, however, that such transactions were restricted under the EAA, the basic legislative authority for national security and foreign policy export controls. ${ }^{24}$

Second, the United States restricted re-exports to the Soviet Union by foreign buyers of controlled U.S.-origin equipment and technology ${ }^{25}$ and, by analogy, foreign exports of locally manufactured equipment that contained controlled U.S.-origin parts, components, or materials or that was the "direct product" of controlled U.S.-origin technology. ${ }^{26}$ All of these re-export-type controls applied even if the U.S.-origin products or technology on which regulation was predicated had been exported before the controls were imposed. ${ }^{27}$ At least in the case of product-of-technology controls, which previously had been applied only prospectively, and then only to foreign

22. See 47 Fed. Reg. 27,250, 27,252 (1982) (amending 15 C.F.R. $\$ 385.2(\mathrm{c})$ ). The restriction extended to foreign corporations and other organizations "owned or controlled" by United States corporations, citizens or residents, or other persons actually within the United States. Id.

23. See Thompson, United States Jurisdiction over Foreign Subsidiaries: Corporate and International Law Aspects, 15 LAW \& POL'y INT'L Bus. 319 (1983). Although the controls instituted under the emergency statutes were for the most part originally imposed during hostilities or other incidents affecting national security, many have remained in effect for decades since the incident that originally justified them, and have for some time been justified on foreign policy grounds, not as emergency measures in the literal sense. See 15 C.F.R. $\$ 385.1$ (1986) (North Korea, Vietnam, Cambodia, and Cuba).

24. Congress amended the EAA to authorize extraterritorial controls only in 1977. See Abbott, Linking Trade, supra note 17 , at 746-47.

25. The restriction on re-exports was part of the December 1981 regulations discussed in note 1. See Abbott, supra note 1, at 79-86.

26. The restriction on the re-export of controlled U.S.-origin parts, components and materials incorporated into end-products abroad was imposed in December 1981 , but its applicability to components previously exported from the United States was unclear. The December 1981 controls also restricted prospectively the export from the United States of controlled technology. Under the Export Administration Regulations (EAR), this had the effect of automatically restricting any subsequent licensees of such technology from exporting its direct products to the Soviet Union. The June 1982 regulations extended both these restrictions to items and technologies that had already been exported from the United States, greatly increasing their economic impact. See Abbott, supra note 1 , at 84-88. See also infra note 27.

27. The December 1981 regulations were explicitly retroactive, in the sense described in the text, in their application to re-exports of controlled end products and technologies. Under the general re-export provisions in the $\mathrm{EAR}$, which became applicable when exports of gas transmission equipment and technology were controlled, the need for a United States re-export authorization was to be judged "at the time of re-export." It was unclear under the 1981 regulations whether the restrictions on re-exports of parts, components, and materials were similarly retroactive, but the 1982 regulations explicitly made them so. See supra note 26.

The 1981 regulations restricting foreign exports of the direct products of controlled U.S.-origin technologies were intended to operate prospectively, affecting only foreign firms that received such technologies, in licensing transactions, for cxample, after the regulations came into effect. The 1982 regulations, however, extended the restriction to any prior recipient of U.S.-origin technologies of the types controlled in $\mathbf{1 9 8 1}$ if (1) its license agreement or a similar contract with its U.S. supplier contained a commitment to abide by U.S. export control regulations, or (2) even in the absence of such a commitment, if the U.S.-origin technology was the subject of a licensing agreement from a "U.S. person," or if its use was subject to the payment of royalties or similar amounts to such a person. See supra note 26; Abbott, supra note 1, at 84-87; Ellicott, supra note 3, at 8-11. 
licensees that had given "written assurances" of compliance, the retroactivity feature was also unprecedented. ${ }^{28}$

The Western allies of the United States vigorously protested these controls. ${ }^{29}$ Both Britain and France formally countermanded at least some of them, leaving the affected firms subject to directly conflicting regulations. ${ }^{30}$ When those firms complied, out of necessity, with the orders of the local sovereign, the United States suspended their right to participate in further export transactions. ${ }^{31}$ Soon, however, the United States withdrew both the controls and the penalties as part of a transparently one-sided settlement with its European allies. ${ }^{32}$

\section{III}

\section{International Cooperation and Collective Goods}

The first of the structural problems relevant to this controversy is the difficulty of achieving international cooperation in a system of sovereign, independent, and self-interested states when cooperative action is necessary to achieve state goals. This is one of the most fundamental problems in international politics. ${ }^{33}$

Cooperation is certainly possible: An example from the field of trade controls is the Coordinating Committee on strategic experts (COCOM) ${ }^{34}$ the informal international organization through which the Western industrial countries coordinate their restrictions on high-technology exports to the Soviet Union. To the extent that COCOM deals with products having direct and significant military applications, however, it may reflect state preferences that are relatively conducive to cooperation. ${ }^{35}$ Those preferences seem to

28. See Abbott, supra note 1, at 95-96. The December 1981 regulations had followed the traditional format, requiring subsequent licensees of controlled technologies to give "written assurances" and restricting their exports of direct products of the technologies. See id. at 85-86.

29. See EC Comments, supra note 5.

30. See 3 A. LoWENFELD, supra note 2 , at 294-96.

31. See id. at 296-300.

32. See id. at 300-06.

33. See, e.g., R. Keohane, After Hegemony: Cooperation and Discord in the World Political Economy 5-11 (1984) [hereinafter R. Keohane, After Hegemony]; Oye, Explaining Cooperation Under Anarchy: Hypotheses and Strategies, 38 WorLd POL. 1 (1985) [hereinafter Oye, Explaining Cooperation]. Achieving cooperation in a world of independent egoists is a pervasive problem of human society generally. See R. Axelrod, The Evolution of Cooperation (1984).

34. For discussions of COCOM, see Berman \& Garson, United States Export Controls-Past, Present. and Future, 67 Colum. L. Rev. 791, 834-42 (1967); Special Report of the President on Multilateral Export Controls, reprinted in Export Administration Act: Agenda for Reform: Hearings Before the Subcomm. on International Economic Policy and Trade of the House Comm. on International Relations, 95th Cong., 2d Sess. 52 (1978); Hunt, Mulilateral Cooperation in Export Controls-The Role of COCOM, 14 U. TOL. L. REv. 1285 (1983); Comment, COCOM: Limitations on the Effectiveness of Multilateral Export Controls, 1983 Wisc. InT'L L.J. 106; Aeppel, The Evolution of Multilateral Export Controls: A Critical Study of the CoCom Regime, 9 Fletcher F. 105, 117-24 (1985).

For a discussion of the means of achieving international cooperation in the context of U.S.European differences on East-West trade, see Crawford \& Lenway, Decision Modes and International Regime Change: Western Collaboration on East-West Trade, 37 WorLD POL. 375 (1985).

35. See Mastanduno, Strategies of Economic Containment: U.S. Trade Relations unith the Sorriet Linion, 37 WORLD POL. 503, 525 (1985). 
correspond at least roughly to the game theory scenario known as Stag Hunt. ${ }^{36}$ In the Stag Hunt game, the desired goal can only be achieved with unanimous cooperation, and all of the players see unanimous cooperation as the most desirable outcome. No player, however, will continue to cooperate if even one other player defects, or appears likely to do so: it would then be impossible to achieve the original goal, and continued cooperation might hamper an individual player's pursuit of second-best goals. ${ }^{37}$ Cooperation may thus break down, even though all of the players desire it, because of uncertainty over others' likely courses of action.

In COCOM, the outcome favored by all the member states, at least regarding products with direct and significant military applications, is a joint embargo. Yet no member state, with the possible exception of the United States, is prepared to restrict exports of such products if it believes, rightly or wrongly, that another member state will export them in its stead. If the Soviets are going to obtain the products in any event, one may as well compete for the sale. Again, uncertainty can cause cooperation to break down.

Since cooperation is the most desired outcome, however, as in Stag Hunt situations generally, all that is needed to maintain cooperation is a mechanism for providing satisfactory information about the intentions of the players. With such a mechanism in place, each player has some reasonable assurance that no other is likely to defect. ${ }^{38}$ Through its embargo lists and periodic consultation procedures, COCOM continuously provides all member states with current, reliable information as to the items that others are willing to embargo, thus allowing the desired cooperation. ${ }^{39}$

In many areas, however-including the control of exports beyond those with direct military applications-international cooperation is much more difficult to achieve, even among states having more or less common goals. ${ }^{40}$ The transaction costs of international bargaining are high; ${ }^{41}$ there are severe information problems; ${ }^{42}$ and, as OPEC has discovered, there are often powerful incentives pulling against cooperation, even at the expense of optimal results. These incentives are often illustrated by the famous game theory scenario known as the Prisoners' Dilemma, a scenario less conducive to

36. For discussions of the Stag Hunt game, see Oye, Explaining Cooperation, supra note 33, at 8; Jervis, Cooperation linder the Security Dilemma, 30 World Pol. 167 (1978). The Stag Hunt senario was originated by Rousseau. See Oye, Explaining Cooperation, supra note 33, at 8 n.16.

37. The preference ordering of the players in a Stag Hunt game, then, is as follows: (1) Mutual cooperation; (2) defecting while others continue to cooperate; (3) mutual noncooperation; and (4) continuing to cooperate while others defect. See Oye, Explaining Cooperation, supra note 33, at 8.

38. Arthur Stein refers to Stag Hunt as the "assurance game." See Stein, Coodination and Collaboration: Regimes in an Anarchic World, 36 INT'L ORG. 299, 302-04 (1982).

39. See Mastanduno, Strategies of Economic Containment, supra note 35, at 525.

40. See Axelrod \& Keohane, Achieving Cooperation Under Anarchy: Strategies and Institutions, 38 World POL. 226 (1985).

41. See R. Keohane, After Hegemony, supra note 33, at 18.

42. See id. at $18,82-83$. 
cooperation than Stag Hunt. ${ }^{43}$ The best example of that scenario is the production of collective goods (CGs). ${ }^{44}$

A CG has two defining characteristics. First, it can be used or consumed by any number of persons-or states-without reducing the amount available for others. ${ }^{45}$ Second, states that do not contribute toward the cost of producing the good cannot feasibly be prevented from using it.46 When contributions toward the cost of producing such a good are voluntary, each state has a strong incentive to free-ride, that is, to disguise its true preference for the good, hope that others will contribute enough to produce it, and enjoy it once they do. ${ }^{47}$ The results typically create a sense of unfairness, in that less of the good gets produced than is actually desired, and the free-riders profit more than those who ante up. ${ }^{48}$

Within domestic society, these problems normally lead us to shun reliance on voluntary contributions for the production of important CGs like national defense. Rather, we mandate more or less equitable contributions, in the form of taxes, toward the cost of those CGs that our legislatures decide should be produced. ${ }^{49}$ In the decentralized international system, however, this approach is not normally feasible, and the problem of cooperation in the production of CGs must be dealt with on an ad hoc basis. ${ }^{50}$

States, like persons, can have different preferences for the same good. Some may value it highly while others do not want it produced at all. ${ }^{51}$ States that genuinely oppose the production of a good and refuse to contribute toward it are not free-riding. Unfortunately, in the real world it is often

43. There are many situations in international politics where states face incentives to act in ways that appear to be in their own interest, but which in fact-when all states follow the same incentives-produce less than optimal results for the group of states and for individual state actors. International relations theorists often model these situations using the Prisoners' Dilemma matrix. See R. Keohane, After Hegemony, supra note 33, at 6-8; Stein, supra note 38; Snyder, "Prisoner's Dilemma" and "Chicken" Models in International Politics, 15 INT'L STuD. Q. 66 (1971); Conybeare, Public Goods, Prisoners' Dilemmas and the International Political Economy, 28 INT'L STud. Q. 5 (1984).

The preference ordering of each player, or state, in a Prisoners' Dilemma game is as follows: (1) Defecting from the cooperative course of action while others are restraining themselves; (2) mutual cooperation; (3) mutual noncooperation; (4) restraining oneself while others are defecting. See Oye, Explaining Cooperation, supra note 33, at 7-8.

44. See Russett \& Sullivan, Collective Goods and International Organization, 25 INT'L OrG. 845 (1971).

45. This quality is referred to as jointness of supply or nonrivalry in consumption. See W. Riker \& P. Ordeshook, An Introduction to Positive Political Theory 260 (1973); Conybeare, supra note 43, at 6 . Most jointly supplied goods exhibit some degree of rivalry, however.

46. This quality is referred to as non-excludability. Excludability is rarely if ever impossible in principle, merely costly and difficult. See Snidal, Public Goods, Property Rights and Political Organizations, 23 InT't STUd. Q. 532, 540-41 (1979). The devices by which states try to prevent noncontributors from sharing in a CG are of particular interest in world politics. See id. at 539.

47. See W. Riker \& P. Ordeshook, supra note 45, at 250-52; Conybeare, supra note 43, at 6 .

48. See W. Riker \& P. Ordeshook, supra note 45, at 247, 250-52; Conybeare, supra note 43, at 6. The incentives facing potential beneficiaries of a CG are essentially those of the Prisoners' Dilemma game. See supra note 43; Conybeare, supra note 43, at 8 .

49. See D. Mueller, Public Choice $15-18$ (1979).

50. See Russett \& Sullivan, supra note 44 , at $846,850-59$.

51. An obvious example is a strategic weapons system, belonging, say, to the United States. This system may be a CG for the citizens of the United States and for the members of NATO, but it is clearly not a CG for the USSR and the states of the Warsaw Pact. See Russett \& Sullivan, supra note 44 , at 848 . 
difficult to distinguish between free-riding and honest opposition. ${ }^{52}$ States can perceive free-riding in others when it does not really exist, and fail to recognize it when it does.

As students of international politics have long realized, the relations among the states of the Western alliance fit neatly into this theoretical scheme. ${ }^{53}$ The United States sees itself as the leader of the West. ${ }^{54}$ It takes a more activist and moralist position on many issues than do its allies ${ }^{55}$ - which this article will refer to generically as "Europe." It often takes unilateral actions as a way of asserting its leadership and encouraging other states to cooperate. ${ }^{56}$ Because of its vast economic power, the United States relies heavily on economic sanctions. ${ }^{57}$ As Europe has become stronger, however, its cooperation in sanctions and other activist measures has become essential. 58

52. Because of this difficulty, actors who wish to benefit from a CG without contributing toward it are often able to disguise or hide their preference for the good. See Conybeare, supra note 43, at 6; D. Mueller, supra note 49 , at 25-26, 68 .

53. Some of the earliest studies of CG's focused on international alliances. See e.g., Olson \& Zeckhauser, An Economic Theory of Alliances, 48 REv. of Econ. \& Statistics 3 (1966), reprinted in B. Russetr, Economic Theories of International Politics 25-45 (1968). Olson and Zeckhauser sought to explain why the United States bore a disproportionate share of the costs of the NATO alliance, even though Europe was closer to the "front" and less able to defend itself independently. Their analysis demonstrated that, whenever the products of an alliance are CG's, the nation that places the highest absolute value on them will bear a disproportionate share of their costs, except in a true emergency, and suboptimal amounts will be produced. Olson and Zeckhauser were careful to observe that this result flows from the national interests of the parties to the alliance, not from any moral failing, such as a tendency to cheat. Thus, moral suasion of the smaller members is inappropriate, and is likely to be ineffective and create resentment. The large nation, moreover, is typically limited in its ability to force larger contributions, because its threat to drop out of the alliance is usually hollow. See id.

As NATO has come to produce more conventional defense, which can be appropriated to a particular member country more easily than strategic defense, the products of the alliance have come to include more private and fewer collective goods, and the smaller alliance members have increased their proportionate contributions. See Cornes \& Sandler, Easy Riders, Joint Production, and Public Goods, 94 ECON. J. 580 (1984).

54. See Secretary of State Shultz, Trade, Interdependence, and Conflicts of Jurisdiction, supra note 4, at 34 ("As the largest free nation, the United States must use the full range of tools at its disposal to meets its responsibility for preserving peace and defending freedom.").

55. The difference has led to popular caricature of the U.S. and European positions, perhaps best captured by The Economist, which paints Europe as a diminutive businessman holding a briefcase and a daffodil-"Pale Ebenezer"-and the United States as a muscular cowboy holding a smoking revolver-“"Roaring Bill." Bill and Ebenezer, Economist, Apr. 26, 1986, at 13.

56. Such unilateral actions are a common strategem of alliance leaders and "hegemonic" states. In addition to highlighting a common problem and setting an example, unilateral action demonstrates the leader's commitment to the cause, assuring other governments that they will not, for example, be left restricting potentially lucrative trade opportunities for their firms while the leader's firms continue trading with the target. See Crawford \& Lenway, supra note 34 , at 380-81. It is of course frustrating to the leader to convey this assurance through costly unilateral action and then find that no other states are cooperating. This is a version of the collective goods problem.

57. See G. Hufbauer \& J. Schott, Economic Sanctions Reconsidered 7, 13-20 (1985) (United States was involved in fully two thirds of all uses of economic sanctions for foreign policy purposes since World War I).

58. In the case of export controls, the economic strength of Europe and other countries is reflected in the pervasive problem of "foreign availability" of controlled goods and technologies. See Abbott, Linking Trade, supra note 17, at 800-10. For a discussion of the importance of multilateral cooperation in export controls, see Moyer \& Mabry, supra note 2, at 158-61. 
It is fair to say that the United States is often frustrated ${ }^{59}$ by its inability to obtain this cooperation on what seem to be matters of common interest. ${ }^{60}$ One recent and controversial example occurred following the 1986 bombing of Libya by U.S. forces, an action widely deplored in Europe. ${ }^{61}$ "Senior American officials" said that the bombing might not have been necessary had Europe been willing to cooperate in economic sanctions against the Qadaffi government, rather than leaving the United States to deal unilaterally with that government's support of terrorism. ${ }^{62}$

The United States perceives this lack of international cooperation, both in the Libyan case and more generally, as a CG problem. In its view, virtually all American export controls, at least to the extent they are successful, produce CGs: weakening the Soviet Union militarily, ${ }^{63}$ for example, or placing a cost on and thus deterring aggression (as in Afghanistan), ${ }^{64}$ the seizure of diplomats (as in Iran), ${ }^{65}$ or the support of terrorism (as with Libya). ${ }^{66}$ Europe benefits from these effects along with the United States, but refuses to join in significant multilateral controls. ${ }^{67}$ Viewed in this way, Europe is free-riding

59. See, e.g., Export Administration Amendments Act of 1985, Pub. L. No. 99-64, 99 Stat. 120 (1985) (amending 50 U.S.C. $\$ \$ 2401-20$ (1982)) ("Availability to controlled countries of goods and technology from foreign sources is a fundamental concern of the United States and should be eliminated through negotiations and other appropriate means whenever possible.").

60 . When allies are dependent on the protection of an alliance leader, they may be willing to cooperate with the leader's program, even if it is to some extent inconsistent with their interests, out of fear of abandonment. In the current world situation, however, Europe has little fear of being abandoned by the United States, and it is relatively free to dissociate itself from American policies with which it disagrees and to try to restrain American actions. See Snyder, The Security Dilemma in Alliance Politics, 36 World Pol. 461, 483-85 (1984).

61. See, e.g., Bill and Ebenezer, supra note 55, at 13 ("Nothing has so vehemently separated America from Europe since 1945.").

62. See N.Y. Times, Apr. 15, 1986, $\$$ A, at 11 , col. 1. American officials and private commentators alike had criticized European reluctance to cooperate in sanctions in the weeks leading up to the bombing. See, e.g., N.Y. Times, Apr. 7, 1986, § A, at 1, col. 3; Apr. 8, 1986, § A, at 31, col. 5; Apr. 13, 1986, \& IV, at 2, col. 3 .

63. This is, in an oversimplified statement, the aim of U.S. national security controls under $\$ 5$ of the EAA. Section 5(a)(1), 50 U.S.C. $\$ 2404$ (a)(1) (1982), authorizes the President to control exports in implementation of the policy laid out in $\S 3(2)(\mathrm{a})$. Section $3(2)(\mathrm{a}), 50$ U.S.C. $\$ 2402(2)(a)$ (1982), states that it is the policy of the United States to restrict exports of goods and technology that would "make a significant contribution to the military potential of any other country which would prove detrimental to the national security of the United States." See also 50 U.S.C. § 2404(d) (1982) (Section 5(d) requires the Executive branch to limit national security controls, to the maximum extent consistent with the purposes of the EAA, to "militarily critical goods and technologies," defined to include certain types of equipment and know-how "which, if exported, would permit a significant advance in a military system" of a controlled country.).

64. For a description of the economic sanctions employed by the United States following the Soviet invasion of Afghanistan, see 3 A. Lowenfeld, InTERnational Economic Law, supra note 2, at 233-67; Moyer \& Mabry, supra note 2, at 27-60.

65. For a description of the economic sanctions employed by the United States following the seizure of the United States embassy in Iran, see 3 A. Lowenfeld, International Economic Law, supra note 2, at 539-621; Moyer \& Mabry, supra note 2, at 8-27.

66. For a description of the economic sanctions employed by the United States against Libya for its support of international terrorism, see Ellicott, The United States Embargo on Trade and Financial Dealings with Libya, 2 InT'L Bus. \& Trade L. Rep. 17 (1986); Bialos \& Juster, The Libyan Sanctions: A Rational Response to State-Sponsored Terrorism, 26 VA. J. INT'L L. 799 (1986); Aвbotr, Economic Sanctions and State-Sponsored Terrorism, Vand. J. Transnat'L L. (forthcoming 1987).

67. Europe did impose sanctions on Iran during the hostage crisis, but these were widely seen in the United States as too limited to be of great effect. See Moyer \& Mabry, supra note 2, at 15-20. 
on the American controls and profiting unfairly; 68 perhaps even more importantly, the allies are undermining the production of essential CGs.

Europe sees the situation much differently. It views itself not as freeriding, but as having different preferences from those of the United States. Sometimes, it argues, it opposes creation of the "good" which the United States seeks to produce, as in the case of the pipeline. ${ }^{69}$ In such a situation, even unilateral American sanctions, to the extent they have any effect, create what is from Europe's point of view a "collective bad" or "negative externality" - the sort of economic effect usually illustrated by a factory belching smoke and pollution into surrounding neighborhoods. ${ }^{70}$ Europe has no interest in cooperating in such a case; a joint embargo would bring about Europe's least favored outcome, a complete reversal of the cooperative Stag Hunt scenario. ${ }^{71}$ Even more frequently, Europe alleges, it opposes the use of trade controls as the means of producing international goods, because given their cost, they are ineffective or even counterproductive. ${ }^{72}$ On this score too, Europe resists cooperation. And if states like Britain, France, and West Germany disagree with the United States over the desirability of certain "goods" and the means of producing them, even greater opposition is likely among states that share fewer common interests with the United States. ${ }^{73}$

These differences of perception lie behind many of the disputes in the export control area: over the coverage of COCOM controls, over cooperation in foreign policy controls, and in part, over extraterritorial controls. American frustration over what it sees as free-riding, in particular, results in periodic efforts to coerce European cooperation, as under the Battle Act; ${ }^{74}$ to

68. The same complaint is often addressed to Europe and Japan in connection with the sharing of defense costs. See supra note 53 .

69. To be clear, the good which the United States sought to produce through the use of sanctions was preventing or delaying completion of the pipeline, as a means of avoiding European dependence on the Soviet Union as a source of energy, preventing the Soviets from earning hard currency from natural gas exports, and other results of the project which it thought undesirable. Europe, on the other hand, generally favored the pipeline as a way to diversify its energy sources away from the Middle East, establish commercial links with the Soviets, and not incidentally provide jobs for European economies. See 3 A. Lowenfeld, International Economic Law, supra note 2, at 273-91.

70. See, e.g., Coase, The Problem of Social Cost, 3 J. L. \& Econ. 1, 1-2 (1960).

71. See supra notes 36-37 and accompanying text. Mutual cooperation-a joint embargo-would ensure that the pipeline would not be built and would prevent Europe from making any related export sales. Europe's most favored outcome would be either (a) mutual noncooperation, that is, no embargo by either the United States or Europe, or (b) a unilateral embargo by the United States. The latter would be preferred if the United States could not restrict enough crucial components to stop the pipeline by itself-the pipeline would be built and Europe would make all the related export sales-while the former would be preferred if it could.

72. See 3 A. Lowenfeld, International Economic Law, supra note 2, at 290 (quoting Andre Fontaine, editor-in-chief of Le Monde; Root, Trade Controls That Work, 56 For. Pol. 61 (1984); Mastanduno, supra note 35 , at 517-29 (1985).

73. Even some states in Europe may have sufficiently divergent interests that they frequently differ over the desirability of particular political goods. The leading example is Switzerland, which is agressively neutral on nearly all issues of international politics. See Hoechner $A$ Suriss Perspective on Conficts of Jurisdiction, Law \& Contemp. Probs., Summer 1987, at 271.

74. Mutual Defense Assistance Control Act of 1951, Pub. L. No. 213, §§ 101-05, 202-03, 30135, 65 Stat. 644 (repealed 1979). The Battle Act authorized the State Department to terminate military and economic assistance to any nation that did not cooperate in the U.S. embargo of the 
purchase such cooperation, as by offering contracts to foreign firms whose home governments agree to restrict technology sales to the East; ${ }^{75}$ or simply to demand cooperation, as the 1985 amendments to the EAA seem to require the President to do. ${ }^{76}$

As they are in every social group, such deep-seated differences between nations will be difficult to bridge. While they persist the extraterritoriality dispute will be very difficult to resolve. Perhaps the best suggestion, though hardly an earthshaking one, is to increase the level of consultation among the allies, preferably within established organizations, on relevant issues. First, more extensive consultations should be held on the foreign policy issues underlying incidents like Libya and the pipeline. Technically, such consultations are already the policy of the United States, or at least of the Department of State. ${ }^{77}$ Separate consultations, perhaps, should be held on economic sanctions and alternate means of implementing policy. ${ }^{78}$ The information provided by the consultations might help the United States recognize when Europe has genuinely different preferences, and conducting the consultations within institutions that Europe values might reduce its incentive to distort its preferences. ${ }^{79}$ These consultations, however, are unlikely to solve the problem completely.

\section{IV}

\section{Mobile Resources and the Static State}

The second structural problem underlying the extraterritoriality debate is the gap between the way the international community defines the statestatically, by reference to fixed geographical boundaries ${ }^{80}$-and the highly mobile nature of a state's resources.

Soviet Union. It was repealed in 1979 as obsolete by the Export Administration Act of 1979.50 U.S.C. § $2416(\mathrm{e})(1982)$.

75. See Crawford \& Lenway, supra note 34 , at 381 .

76. Section 5 of the EAA, 50 U.S.C. $\$ 2404$ (1982), requires the President to negotiate with the other member states of COCOM with a view toward accomplishing certain specified objectives. In the 1979 version, the broadest such objective was the reduction in the scope of COCOM controls to a level acceptable to and enforceable by all member governments. Id. The Export Administration Amendments Act of 1985, supra note 59, amended this section by striking out the objective just described and adding six new ones, all relating to the strengthening of COCOM controls. e.g., to "improve the International Control List and minimize the approval of exceptions to that list, strengthen enforcement and cooperation in enforcement efforts, provide sufficient funding for the Committee, and improve the structure and function of the Secretariat. . . " 50 U.S.C. § 2404 (i)(5) (1982).

77. See Dam, Extraterritoriality, Conficts of Jurisdiction, and L'nited Stales Foreign Policy, supra note 4, at 16-22 (When disputes over jurisdiction are grounded in disputes over policy, the most effective solution is to harmonize policy. The United States will seek to resolve the policy differences that underlie many jurisdictional conflicts.); Secretary of State Shultz, Trade, Interdependence, and Conficts of Jurisdiction, supra note 4 , at 36 (outlining steps to avoid conflicts and minimize harm when unavoidable conflicts do occur).

78. See Crawford \& Lenway, supra note 34 , at $386-87$.

79. See id. at 386-87; Oye, supra note 33, at 17; Axelrod \& Koehane, supra note 40, at 241; R. Keohane, After Hegemony, supra note 33, at 102.

80. See Restatement (Revised) Draft No. 6, supra note 14, § 201 ("Under international law, a 'state' is an entity which has a defined territory and permanent population, under the control of its 
The territory of a state is not valuable solely because of its sheer square footage, but also, perhaps primarily, because it carries with it control over resources, both tangible and intangible, that can be translated into wealth and power. ${ }^{81}$ Much the same can be said of population. ${ }^{82}$ While it is recognized that a state may have a legitimate interest in regulating the conduct of its citizens even while they are abroad, ${ }^{83}$ however, the state's interest in preserving some control over resources dispersed abroad through commerce and investment is not so clearly accepted.

The extraterritorial aspects of the U.S. export control system reflect that interest by asserting a limited right to control certain resources that are-for want of a better term-functionally associated with the United States, even though they are physically outside its boundaries. In some cases, functional links to the United States are inherent in the way the resources are used abroad. In other cases, the United States must act to maintain functional links that might otherwise be broken as resources leave its territory. ${ }^{84}$ In both situations, the aim of asserting control is to maximize the effectiveness of unilateral American action, in a world where cooperation is difficult and allies do not always follow the example of their leader, by mobilizing all the resources associated with the state. In CG situations, more specifically, the aim is to limit the extent to which resources associated with the United States are used by others as instruments of free-riding.

The clearest example of inherent functional links is the controlled foreign subsidiary of an American corporation. ${ }^{85}$ The heart of the foreign subsidiary is a bundle of resources, including equity capital, technology, and managerial know-how. These resources typically have been provided by the American parent and transferred out of the United States. The subsidiary is usually controlled from the United States by its parent, sometimes even on operational details, and relies on frequent parental infusions of technical and managerial information. The subsidiary's profits are normally mingled with those of the entire enterprise, and are invested or remitted to the parent on its

own government, and which engages in, or has the capacity to engage in, formal relations with other such entities.").

81. This statement owes much to the perspective set forth in M. MCDougal \& W.M. Reisman, International Law in Contemporary Perspective: The Public Order of the World Community 432-34 (1981) (elaborated at 435-787).

82. See id. at $788-89$.

83. See Restatement (Revised) Draft No. 6, supra note 14, $\$ 402$ (2) ("Subject to $\$ 403$, a state has jurisdiction to prescribe law with respect to ... (2) the activities, status, interests or relations of its nationals outside as well as within its territory.").

84. Cooper refers to the effort "to extend national control to the mobile factors wherever they be" as the "agressive" response to greater economic interdependence, specifically the problems that arise when the decisions of firms cover a wider geographic area than the jurisdiction of government. Cooper, Economic Interdependence and Foreign Policy in the Serenties, 24 WorLd Poi.. 159, 168-70 (1972). This is quite different from the other main source of extraterritoriality disputes, the assertion of jurisdiction over foreign anticompetitive acts that affect the allocation of resources within United States territory. See Restatement (Revised) Draft No. 6 supra note $14, \$ 415(2)$.

85. See Abbott, supra note 1, at 96-98. 
instructions. ${ }^{86}$ While the foreign subsidiary certainly has important links with its host country, almost always including local employees and sometimes including local equity holders, ${ }^{87}$ its links with the United States are significant as well.

If foreign subsidiaries could escape American regulation entirely, moreover, U.S. multinationals could free-ride on other American firms, avoiding the impact of export controls or other forms of territorial regulation simply by transferring resources out of U.S. territory. ${ }^{88}$ Such transfers might benefit the recipient states but could significantly reduce the economic power of the United States thus reducing its ability to provide both private goods, of value primarily to itself, and international collective goods.

In the case of goods and technology exported to independent foreign firms, the United States attempts to maintain the functional links inherent in American origin by imposing restrictive conditions on purchasers at the time of the original sale ${ }^{89}$ The use of such restrictions, rather than any claim that goods or technology have a continuing American "nationality"-a notion enthusiastically demolished by numerous commentators ${ }^{90}$-appears to be the basic justification for the array of re-export-type controls the United States maintains. ${ }^{91}$ In essence, the United States says: These resources comprise important bases of our power, and they may be taken abroad only on the conditions we set; if you breach those conditions, we will penalize you in certain established ways. The rationale is even clearer when one considers that in the great majority of export control enforcement cases, especially those involving foreign firms, the only penalty invoked is a suspension of the right to participate in further exports from the United States. ${ }^{92}$ Because of this, the United States can usually be understood to say: If you breach the

86. See id. at 96-98. For a discussion that emphasizes the practical constraints on centralized control of foreign subsidiaries at the level of routine management decisions, see D. VAGrs, Transnational Business Problems $111-14$ (1986).

87. See D. VAGTs, supra note 86 , at 113 .

88. See Abbott, supra note 1, at 97-98, 109-10. As the term "free-riding" suggests, such transfers are part of a separate CG problem internal to the United States.

89. See Post-Hearing Brief of U.S. Department of Commerce, supra note 5, at 48-50. See also Feldman, supra note 8, at 264-65; Marcuss \& Richard, supra note 8, at 440-41.

90. See, e.g., Note, Extraterritorial Application of the E.AA, supra note 3, at 1324-25; EC Comments, supra note 5 , at 894 .

91. It must be admitted that the government has not made its justification for such controls crystal-clear, and has advanced justifications other than the imposition of restrictive conditions in specific contexts. In the Dresser (France) litigation, for example, the government argued that the use by Dresser (France) of previously licensed U.S.-origin technology constituted a "continuing export", which could, presumably, be regulated by the United States under the territorial principle. See Defendent's Memorandum of Points and Authorities in Opposition to Application for a Temporary Restraining Order, at 225, Dresser Indus., Inc. v. Baldridge, 549 F. Supp. 108 (D.D.C. 1982); Morse \& Powers, supra note 3 , at $562 \mathrm{n} .118$.

92. A classic case is Raytheon Manufacturing Co., 24 Fed. Reg. 2626 (1959), reprinted in 3 A. Lowenfeld, International EConomic Law, supra note 2, at 30. Suspension of export privileges was also the penalty invoked against foreign licensees shipping direct products of U.S.-origin technolog: in violation of the 1982 pipeline regulations. See, e.g., Case 635, 47 Fed. Reg. 40,205 (1982) (order temporarily denying export privileges to John Brown Engineering Ltd.). See Restatement (REviSED) Draft No. 6, supra note $14, \S 431$ reporters' note 3 . 
conditions we have established on the use of our resources, we will restrict your ability to buy more.

Such conditions are sometimes expressly acknowledged, as in the "written assurances" required of licensees. ${ }^{93}$ Even where they are not acknowledged, however, ${ }^{94}$ the United States would argue that the purchase of American exports with knowledge of the applicable conditions constitutes an implied agreement to comply with them..$^{95}$ The same logic, it seems, would support conditions stating that additional restrictions may be imposed in the future. An example of such a condition is the U.S. regulation providing that the need for authorization of a re-export is to be determined at the time of the proposed transaction, not when the goods are first taken from the United States. ${ }^{96}$ In all such cases, foreign firms which are aware of the conditions can bargain for a lower price, thus reducing not only the amount they themselves must pay, but also, in most cases, the value of the resources their home states must give up in exchange for U.S.-origin goods or technology. ${ }^{97}$

The United States has not always acted in ways that are consistent with the above rationale. The validity of consent, express or implied, turns on adequate notice, and some of the retroactive 1982 restrictions, for example, were by no means clearly authorized under prior regulations and practice. ${ }^{98}$ American re-export restrictions, furthermore, purport to apply to any subsequent holder of U.S.-origin items in a chain of ownership, although only in a few instances are subsequent purchasers required explicitly to accept them. ${ }^{99}$ Finally, the "written assurances" required of many foreign

93. See 15 C.F.R. $\$ 379.4(\mathrm{f})$ (1986). Even written assurances, however, are addressed to the U.S. exporter and are not required to be phrased as express consents to American regulations. Id. A clearer case of consent is the ultimate consignee and purchaser statement, a form addressed to the U.S. Department of Commerce which many foreign importers must submit as part of an American exporter's application for a validated license. See id. $\$ 375.2$. This form includes an explicit undertaking not to re-export the items covered by the license, without approval, contrary to the U.S. Export Administration Regulations. See Form ITA-629, Item 8, reprinted in P. RAY \& E. HirsChHORN, Guide to Export Controls (1987).

94. For a discussion of situations in which no foreign acknowledgement is required, see Abbott, Linking Trade, supra note 17, at nn. 615-16 and accompanying text; Feldman, supra note 8, at 265-68.

95. See Post-Hearing Brief of U.S. Department of Commerce, supra note 5, at 49.

96. See 15 C.F.R. $\$ \$ 374.2(a), 376.12$ note (1986).

97. See Abbott, supra note 1, at 139.

98. The principal offender was the 1982 restriction on sales of direct products of controlled U.S.-origin technologies. All prior product-of-technology restrictions, including those imposed in December 1981, applied only to foreign licensees that had given, at the time of the original technology export, written assurances that they did not intend to export products of the technologies to specified destinations to which exports from the United States were then controlled. See Abbott, supra note 1, at 95-96. In addition, it was unclear, even after the December 1981 controls, whether re-export controls on foreign-manufactured end products containing U.S.-origin components were intended to be retroactive. See id. at 85.

99. 15 C.F.R. $\$ 374.1$ (1986) purports to prohibit any person in a foreign country, not just the original purchaser, from re-exporting without authorization "a commodity previously exported from the United States." To bind subsequent purchasers, it would seem, the United States would have to obtain their consent directly, or else require the original purchaser to impose a restrictive condition on any purchaser from it, and so on down the chain. Applications for authority to re-export goods to controlled countries and several other destinations where there is perceived to be a high risk of diversion must include an ultimate consignee and purchaser statement provided by the buyer. See 15 C.F.R. $\$ 374.3$ (c)(1) (1986); supra note 93. The consent of subsequent purchasers is not otherwise 
purchasers of U.S.-origin technology are not phrased as express consents to American regulation and typically run to the American exporter rather than to the United States itself. ${ }^{100}$ In principle, however, the rationale is clear, and the regulations could easily be amended to conform more closely with it. One would have thought, in fact, that amendments for just that purposemodifying, among other things, the recent regulations themselves, the destination control notices required to be included on certain export documents, and the undertakings required to be provided by purchaserswould have been made following the pipeline case.

It is important to note that in both the foreign subsidiary and the re-export situations, the United States is only claiming what it sees (or says it sees) as a right of unilateral action-a right to control resources functionally associated with it, assimilating them to resources within its territory, for certain limited purposes-even though it is motivated in part by concern over free-riding. Some might argue that a state in the position of the United States should be permitted to coerce free-riding states, or any firms operating as part of the economies of such states, into optimal contributions toward the production of international CGs. This, however, is not the position of the United States. Its extraterritorial controls are not a reincarnation of the Battle Act ${ }^{101}$ instruments for coercing foreign governments into cooperating. Neither are they efforts to force independent foreign firms to participate actively in its embargoes, like the secondary aspects of the Arab boycott of Israel. ${ }^{102}$ Not even in the embargo regulations promulgated under its emergency laws has the United States threatened to penalize any foreign firm that sells restricted products to a target nation. ${ }^{103}$ The extended unilateral controls of the United States may create negative externalities for other states, and that is unfortunate, but even purely territorial acts may have that effect.

required, however-although some firms may include provisions restricting re-exports in their contracts with distributors-so that frequently "the chain of commitment stops with the first reexport." Feldman, supra note 8 , at 266.

100. See supra note 93. Documents required of some foreign purchasers of American goods, however, do include explicit undertakings addressed to the United States Government. The principal examples are the ultimate consignee and purchaser statement, see supra note 93, and a similar form required of foreign firms seeking qualification as consignees under certain special export licenses. See Form ITA 6052, Item 9, reprinted in P. Ray \& E. Hirschhorn, Guide To ExporT Controls (1987); Feldman, supra note 8, at 265-67.

101. See supra note 74 and accompanying text.

102. For an analysis of the primary and secondary aspects of the Arab boycott and U.S. analogues, see Steiner, International Boycotts and Domestic Order: American Involvement in the Arab-Israeli Confict, 54 TEx. L. Rev. 1355, $1367-70$ (1976).

103. See, e.g., 31 C.F.R. $\$ \S 500.201,500.329-330$ (1986) (prohibitions applicable only to persons subject to jurisdiction of United States). It may be necessary to modify this statement, however, if Congress approves legislation-passed by the Senate as this article went to press-restricting American imports of products of Toshiba Corporation and Kongsberg Vaapenfabrik as a sanction for those firms' exports of foreign-origin products and technology to the Soviet Union in violation of their own national laws, adopted pursuant to COCOM rules, and making such sanctions mandatory in similar future cases. See H.R. 3, 100th Cong., 1 st Sess., 133 Cong. Rec. $\$ 10249$ (daily ed. July 21 , 1987) ( $\S 1031-32$ ) (adoption by Senate). 
Europe does not accept the notion of functionally associated resources, ${ }^{104}$ especially the idea of creating links by private consent, ${ }^{105}$ any more than it accepts the American CG analysis. ${ }^{106}$ On this score Europe probably feels that the United States is the disingenuous one.

Europe adheres to the more traditional static notion of the state, under which resources that freely enter a state's territory become part of that state's power base (at least, in the case of direct investment, if there is local incorporation). ${ }^{107}$ It bases its legal argument primarily on the territorial principle of jurisdiction, ${ }^{108}$ which is part and parcel of the traditional notion that principle "divides the world into compartments, within each of which a foreign state has jurisdiction." 109 These positions seem consistent with European national interests if one accepts the apparent facts that Europe is less activist than the United States, ${ }^{110}$ more reliant on international commerce, and more often the recipient than the source of sensitive goods, technology, and investment.

Because Europe rejects the idea of functional links, it tends to see extraterritorial trade controls not as unilateral action, but as a way of coercing its cooperation and that of its firms. ${ }^{111}$ In economic terms, Europe sees such controls as a form of taxation, forcing it to devote some of its resources to the production of "goods" it may not even want."12 It views the United States as

104. In its Comments on the 1982 pipeline regulations, the EC asserted that the U.S. measures were contrary to international law because their extraterritorial aspects were not consistent with "the two generally accepted bases of jurisdiction in international law, the territoriality and the nationality principles." It contended that the nationality principle did not support jurisdiction over foreignincorporated companies, regardless of the presence of "some corporate link (parent-subsidiary) or personal link (e.g. shareholding) to the U.S.;" and regardless of any "tie to a U.S.-incorporated company ... through a licencing agreement, royalty payments, or payment of other compensation, or because they have bought certain goods originating in the U.S." EC Comments, supra note 5, at 89394.

105. See id. at 895-96.

106. See supra text accompanying notes 69-73.

107. The EC based its legal arguments on the territoriality principle: "the notion that a state should restrict its rulemaking in principle to persons and goods within its territory... is a fundamental notion of international law, in particular insofar as it concerns the regulation of the social and economic activity in a state." EC Comments, supra note 5, at 893 . In the case of foreign subsidiaries, the EC argued that corporations are nationals, solely, of the state where they are incorporated or have their registered office. As to goods and technology, the EC argued that they cannot be seen as having any nationality. The American regulations thus exceeded the authority of the nationality principle, which "exacerbates the infringement of the territoriality principle." Id. at 893-95. For an analysis of the EC Comments, see Lowe, supra note 3.

108. See supra note 107.

109. Mann, The Doctrine of Jurisdiction in International Law, 1964-I Recueil Des Cours 1, 24-30 (Hague Academy of International Law).

110. See supra notes 54-56 and accompanying text.

111. The EC Comments argue that:

E.C. companies are pressed into service to carry out U.S. trade policy toward the U.S.S.R., even though these companies are incorporated and have their registered office within the Community which has its own trade policy towards the U.S.S.R.

The public policy ("ordre public") of the European Community and its Member States is thus purportedly replaced by U.S. public policy which European companies are forced to carry out within the E.C.

EC Comments, supra note 5 , at 895 .

112. See supra notes $69-71$ and accompanying text. 
trying to arrogate to itself powers which are usually given to national governments-to determine what CGs should be produced and to levy taxes to cover their cost ${ }^{13}$-but which are inconsistent with the non-hierarchical, decentralized structure of the international system, ${ }^{114}$ and are not subject to the institutional controls normally placed on domestic governments. ${ }^{115}$ Europe also bases its legal arguments, then, on those "constitutional" principles of international law, like sovereign equality and non-interference, which support this basic structure. ${ }^{116}$ It resists what it sees as American coercion with blocking statutes, like the British Protection of Trading Interests Act, ${ }^{117}$ that raise barriers to foreign penetration around the formal perimeter of the state.

\section{V \\ The Inadequacy of The Applicable Rules}

The positions of both sides in the extraterritoriality controversy reflect fundamental national interests; the American perception of free-riding and the European perception of coercion give each position special emotional force. Unfortunately, the legal doctrines available for dealing with such a controversy appear inadequate for the task, at least in the short run.

This inadequacy is particularly obvious in the case of the territoriality and nationality principles of national prescriptive jurisdiction, the "minimum bases of jurisdiction," on which most commentators have focused. First, those who would rely on these principles must deal with the words of the Permanent Court of International Justice in the case of the S.S. Lotus. ${ }^{118}$ The famous dictum in this "Delphic judgment" 19 would seem to allow the United States freely to extend its jurisdiction abroad, so long as enforcement was

113. See supra note 49 and accompanying text.

114. This notion is implicit in the concept of a territorially-based "ordre public". See supra notes 107-08, 111 and accompanying text. The EC similarly argued that "the interest of the European Community in regulating the foreign trade of the nationals of the Member States in the territory to which the Community Treaties apply is paramount over any foreign policy purposes that a third country may have." EC Comments, supra note 5, at 901 . For a more general discussion, see Lowe, supra note 3, at 519 (public law is the expression of the will of a particular territorial political community and should not be given effect outside the territory when it might affect the public order of another territorial political community).

115. See Snidal, supra note 46 , at 558

116. The EC Comments argue (1) that each state, and the EC insofar as state powers have been transferred to it, "has the right freely to organize and develop its social and economic system," and (2) that the American regulations were "an unacceptable interference in the affairs of the European Community." EC Comments, supra note 5, at 893, 895. See also Lowe, supra note 3, at 519-27 (territorial nature of public law expressed in international law as principles of sovereign equality and non-intervention, as well as rules on national jurisdiction); Bridge, supra note 3, at 8-10 (exterritorial jurisdiction must stop short of interference in proper affairs of another state; this notion is encapsulated in principle of sovereign equality and duty not to intervene in any matter within domestic jurisdiction of another state).

117. Protection of Trading Interests Act, 1980, ch. 11, reprinted in 21 INT'L Legal Materials 834 (1982).

118. France v. Turkey, 1927 P.C.I.J. (Ser. A) No. 10 (the S.S. Lotus case).

119. See Bridge, supra note 3 , at 8 . 
limited to its own territory, unless Europe could establish rules of international law specifically prohibiting it. ${ }^{20}$

Although most commentators have rejected the Lotus dictum, ${ }^{121}$ it continues to receive support in the United States, ${ }^{122}$ and even some European scholars find the case to have authority. P.J. Kuyper, for example, notes that the court explicitly dealt with the general problem of jurisdiction, not only with criminal cases, and clearly separated (a) the extension of legislative jurisdiction to acts outside state territory-acceptable except where prohibitory rules of international law are established-from (b) the exercise of enforcement jurisdiction-limited to state territory unless permissive rules are shown. ${ }^{123}$ Ironically, Kuyper observes that the European Community will probably rely on Lotus as the most authoritative pronouncement on the subject in establishing the reach of its own rules. ${ }^{124}$

Professor Prosper Weil suggests that those who criticize the Lotus decision are attempting to "transcend" historical and political reality in order to establish what they consider a better rule, one that will " "tame' the sovereign power of states." 125 Most of the time, he observes, one cannot trace a welldefined rule of international law on the subject, prohibitory or otherwise; uncertainty prevails. Weil suggests, in a formulation similar to the Lotus opinion, that this uncertainty could be seen as reflecting a permissive rule of international law: States are permitted to apply their rules extraterritorially, but other states are permitted not to recognize or give effect to such rules. This formulation would accurately reflect the current situation while providing a base for gradually strengthening the limiting rules of international law. ${ }^{126}$

The Lotus decision and related theories, like that of Professor Weil, are a far cry from the rigid territorial doctrine officially adopted by Europe. They

120. In the language of the court:

Now the first and foremost restriction imposed by international law upon a State is that - failing the existence of a permissive rule to the contrary-it may not exercise its power in any form in the territory of another state. In this sense jurisdiction is certainly territorial. . . It does not, however, follow that international law prohibits a State from exercising jurisdiction in its own territory, in respect of any case which relates to acts which have taken place abroad, and in which it cannot rely on some permissive rule of international law. Far from laying down a general prohibition to the effect that States may not extend the application of their laws and their jurisdiction of their courts to persons, property and acts outside their territory, [international law] leaves them in this respect a wide measure of discretion which is only limited in certain cases by prohibitive rules; as regards other cases, every State remains free to adopt the principles which it regards as best and most suitable.

France v. Turkey, 1927 P.C.I.J. (Ser. A) No. 10, at 18-19. For a discussion of the Lotus case in a similar context, see Kuyper, European Community Law and Extraterritoriality: Some Trends and New Developments, 33 INT'L \& COMP. L.Q. 1013 (1984).

121. See Mann, supra note 109 , at 33-35.

122. See Small, Managing Extraterritorial Jurisdiction Problems: The United States Government Approach,

Law \& Contemp. Probs., Summer 1987, at 283, 291-92.

123. See Kuyper, supra note 120 , at 1014.

124. See id.

125. Weil, International Law Limitations on State Jurisdiction, in Extra-territorial Application of Laws and Responses Thereto 32-33 (C. Olmstead ed. 1984).

126. See id. at 34-37. 
lend support to the positions of the United States, but seem likely to prolong, rather than resolve, the debate over extraterritoriality.

Second, even short of the liberality of Lotus, there are those who hold that, in today's complex and interdependent world, national prescriptive jurisdiction should not be defined and limited by the rigid categories of territory and nationality. These twin pillars of jurisdiction, derived from the traditional notion of the state and traceable back at least as far as the "maxims" of Joseph Story, ${ }^{127}$ are put forward as the "minimum bases of jurisdiction to prescribe law" ${ }^{28}$ in both the Restatement (Second) ${ }^{129}$ and the Restatement (Revised) of Foreign Relations Law. ${ }^{130}$ They also constitute the starting point in most analyses of extraterritorial regulation. ${ }^{131}$ Yet in his famous 1964 Hague lectures, F.A. Mann pointed out that these absolute rules, developed in an era of wholly different economic, social, and technical conditions, when corporations did not play their current leading role in international life, are unsatisfactory in the modern world. ${ }^{132}$

Mann called for international law to liberate itself from the "shackles" of the Story maxims. ${ }^{133}$ His approach called for evaluating claims of national jurisdiction by assessing all legally relevant contacts between the state asserting jurisdiction and the set of international facts it sought to regulate. He would search for the existence of genuine links between the state and the conduct to be regulated, assess the strength of the state's interests, and look for the "center of gravity" of state contacts. ${ }^{134}$ This approach is strikingly similar to section 403 of the Restatement (Revised) in formulation, but quite different in application. Section 403 establishes the principle of "reasonableness" as a secondary limit on state jurisdiction already established prima facie on the basis of territoriality, nationality, or another basis of jurisdiction. Mann's approach, in contrast, would use a flexible test similar to "reasonableness" to determine the existence of jurisdiction in the first instance. Mann expressly sought to depart from the rigid prima facie rules. Because international law allows for concurrent jurisdiction, ${ }^{135}$ whether another state had equally close, closer, or the closest connection to the conduct to be regulated would be relevant under Mann's test, but not decisive.

It is not entirely clear whether Mann saw his approach as reflecting current law, supported by the state practice he reviewed in his lectures, or as a

127. The Apollon, 22 U.S. (9 Wheat.) 362, 370 (1824); J. Story, Conflict of LAws, §§ 18-22

(1834). For a brief summary of the "maxims," see Mann, supra note 109, at 28.

128. See supra note 14 and accompanying text.

129. The protective and universality principles are also accepted as bases of jurisdiction, see Restatement (Revised) Draft No. 6, supra note 14, $\S 402(3)$, 404; Restatement (Second), supra note $12, \S 10$, but are minor by comparison.

130. See Restatement (Revised) Draft No. 6, supra note 14, § 402.

131. See supra notes $14-16$ and accompanying text.

132. Mann, supra note 109 , at 37.

133. Id. at 43 .

134. Id. at 44-46.

135. Id. at 49 . 
recommendation meant for adoption in the future. ${ }^{136}$ Other eminent scholars, however, have seen in Mann's approach "the master principle of jurisdiction in international law." 137

Mann's theory, like the Lotus opinion, would by no means allow unrestricted exercises of national jurisdiction. ${ }^{138}$ A reasonable relation between a state and the acts it sought to regulate would be required; no abuse of right or arbitrary action would be permitted; and jurisdiction would be limited by the principle of non-interference in the affairs of other states. ${ }^{139}$ Mann himself, moreover, did not apply his theory in ways that would give much comfort to the United States. He opposed both "effects" jurisdiction in antitrust cases ${ }^{140}$ and the assertion of jurisdiction over foreign subsidiaries by the parent corporation's home state. ${ }^{141}$ Still, Mann's theory is a flexible one, and its essential elements-genuine links, reasonable connections, state interests, and concurrent jurisdiction-fit comfortably with both the concept of functionally associated resources and the interest of a state in limiting the use of its resources as instruments of free-riding. The United States' position on extraterritorial regulation, as analyzed here, can be much more easily argued and supported under such a flexible test than under the rigid rules of territory and nationality. ${ }^{142}$ Again, however, like the principle of "reasonableness," this flexible text is more likely to fuel the extraterritoriality controversy than to resolve it.

Third, even if a state must in the first instance ground its regulations in territoriality or nationality, as provided in the Restatement (Revised), ${ }^{143}$ I find those principles broad enough to accommodate many forms of extraterritorial regulation-although Europe ${ }^{144}$ and most commentators ${ }^{145}$ disagree. This is so because the interests the United States is asserting, in an era of multinational enterprises and mobile resources, are similar to those which the principles were originally designed to protect.

136. See id. at 126 .

137. Meesen, International Law Limitations on State Jurisdiction, in EXTRA-TERritorial APPLICATION of Laws And Responses Thereto 38, 41 (C. Olstead ed. 1984).

138. The Lotus court referred to, without discussion, principles of international law that would restrict national jurisdiction. Mann sees as one possible interpretation of Lotus that the Court was seeking to depart from the absolutes of territorial and nationality jurisdiction in favor of a more flexible approach, consistent with his own. See Mann, supra note 109, at 36.

139. Id. at 47-48. Mann saw the principle of non-interference as difficult to apply, however. For further discussion of that principle, see infra notes 174-83 and accompanying text.

140. See Mann, supra note 109, at 104-06.

141. See Mann, Responsibility of Parent Companies for Foreign Subsidiaries, in EXTRA-TERRITORIAL. application of Laws and Responses Thereto 154 (C. Olstead ed. 1984).

142. The United States in fact argues that international law requires only a reasonable nexus with the activities to be regulated; territoriality and nationality are accepted forms of nexus, but not the only ones. See Small, supra note 122, at 292-93.

143. Restatement (Revised) Draft No. 6, supra note 14, 8402 comment a.

144. See EC Comments, supra note 5.

145. See sources cited supra note 8 . 
Regulation of foreign subsidiaries, directly or indirectly, under the nationality principle has been debated for decades. ${ }^{146}$ In general, international law has established the state of incorporation as the corporation's state of nationality for most purposes, although other tests of nationality have sometimes been adopted. ${ }^{147}$ This test, plus the operation of the subsidiary in its host state's territory, gives Europe strong arguments against regulation by the parent company's home state. ${ }^{148}$ Yet the relevance of the functional links to the parent's home state mentioned above can only be denied by the most static- and reductionist-minded. Principle and state practice both lead to the conclusion that foreign subsidiaries have links analogous to nationality with both the host state and the parent's home state. ${ }^{149}$ In most cases, moreover, foreign subsidiaries subject to American regulation have extensive commercial links to the United States, both generally and with regard to particular transactions, in addition to simple ownership or control. ${ }^{150}$ The subtle questions of when, and to what extent, the parent's home state should be able to regulate the subsidiary where host state policies differ from its own are not easily answered by a principle as broad as "nationality," which was designed primarily for a different context. ${ }^{151}$

The Restatement (Revised) accepts the existence of dual links akin to nationality. ${ }^{152}$ It tries to deal with the subtle questions posed above by providing that the jurisdiction of the parent company's home state should be "limited," must be "reasonable," and must only be exercised in "exceptional" cases, defined primarily according to the importance of the regulation to the

146. See Marcuss \& Richard, supra note 8, at 17-20; Craig, Application of the Trading unth the Enemy' Act to Foreign Corporations Owned by Americans: Reflections on Fruehauf v. Massardy, 83 HaRv. L. REv. 588-92 (1969); Thompson, supra note 23, at 364-67; Restatement (Revised) Draft No. 6, supra note $14, \S 414$ comment a, reporters' notes $1-4$.

147. See Restatement (Revised) Draft No, 6, supra note 14, § 216; Marcuss \& Richard, supra note 8 , at $17-19$.

148. See EC Comments, supra note 5, at 893-95.

149. See Restatement (Revised) Draft No. 6, supra note $14, \$ 414$ comments a-b, reporters' notes 1-8; Marcuss \& Richard, supra note 8, at $18-19$ (While in Barcelona Traction, Light and Power Company, Limited (Belgium v. Spain), 1970 I.C.J. 3, the International Court of Justice stated that no test of corporate nationality based on links or "genuine connections" to a state had found general acceptance, the court reviewed such links in deciding that a Canadian-incorporated entity had Canadian nationality.); Thompson, supra note 23, at 361 ("Any attempt to resolve jurisdiction over subsidiaries must begin with a recognition that, because of the transnational character of the enterprise, the interests of two states are inevitably involved.").

150. See Small, supra note 122, at 286. The U.S. anti-boycott statute explicitly applies to foreign subsidiaries only to the extent of their activities in the interstate or foreign commerce of the United States. 50 U.S.C. $\S \S 2407$ (a)(1), 2415 (2) (1982). This is sometimes seen as strengthening the United States' jurisdictional claim. See Marcuss \& Richard, supra note 8, at 453; Steiner, supra note 102, at 1407 n. 298

151. The concept is designed primarily to regulate the relations between states and natural persons. See, e.g., Nottebohm Case, 1955 I.C.J. 1, 23 ("[N]ationality is a legal bond having as its basis a social fact of attachment, a genuine connection of existence, interests and sentiments. . . ."); Restatement (Revised) Draft No. 6, supra note 14, $\$ 216$ reporters' note 1.

152. See Restatement (Revised) Draft No. 6, supra note $14, \$ 414$ comment b. 
parent's home state. ${ }^{153}$ Because that state will make these determinations, however, and because the Restatement would permit concurrent jurisdiction, ${ }^{154}$ the rule will lead to little essential change in the current situation.

Even if direct nationality jurisdiction over foreign subsidiaries were limited, one should note, the United States could proceed almost as effectively - as it often has in the past-by addressing its regulations and penalties to the U.S. parent, or to American officers or directors, over whom it has nationality and territorial jurisdiction. ${ }^{155}$ Such indirect jurisdiction would likely be resisted abroad. ${ }^{156}$ The Restatement, however, makes it easier to justify than direct regulation. ${ }^{157}$

As to re-export-type controls, the United States can argue that it is acting territorially when it imposes conditions on the use of resources proposed for export, ${ }^{158}$ and that the territorial principle is meant to convey precisely this right to regulate the use of state resources. ${ }^{159}$ The Restatement (Revised) can be read generally to support the U.S. position on re-export controls, although it does so incompletely, indirectly, and somewhat tentatively, and does not discuss the idea of restrictive conditions or any other rationale. ${ }^{160}$ The lack of a fuller or more definite treatment is disappointing, but it probably indicates that the law on the subject is too unsettled for restatement, a point similar to that being made here.

153. See id. \$414(1), (2)(b)-(c); Restatement (Revised) Draft No. 7, supra note 11, §403. An earlier version of $\$ 414$, denominated $\$ 418$, provided that it was unreasonable for a parent corporation's home state to regulate the activities of a foreign subsidiary so as to require conduct that is prohibited, or prohibit conduct that is required, by the host state. RESTATEMENT (REVISED) OF Foreign Relations Law of the United States $\$ 418$ (Tent. Draft No. 2, 1981). This prejudgment of the difficult question of reasonableness has been omitted in $\S 414$. For criticism of the earlier draft, see Thompson, supra note 23, at 387-92.

154. See Restatement (Revised) Draft No. 7, supra note 11, § 403(3) comment e; Restatement (Revised) Draft No. 6, supra note $14, \S 414$ comment d.

155. See Thompson, supra note 23, at 357-61, 363-65.

156. See Mann, Responsibilities of Parent Companies, supra note 141, at 155-56.

157. See Restatement (Revised) Draft No. 6, supra note 14, \$414(c) comment c.

158. See Marcuss \& Richard, supra note 8, at 40; Post-Hearing Brief of U.S. Department of Commerce, In re Dresser, supra note 5, at 48-49.

159. See EC Comments, supra note 5, at 893 " "The territoriality principle ... is a fundamental notion of international law, in particular insofar as it concerns the regulation of the social and economic activity in a state."); Post-Hearing Brief of U.S. Department of Commerce, In re Dresser, supra note 5 , at 48 .

160. Section 431(1) of the Restatement (Revised) provides that a state may employ judicial or non-judicial measures to induce compliance or punish noncompliance with its laws and regulations, provided those rules were validly prescribed in accordance with $\S 402$ and 403 , including the principle of "reasonableness." Restatement (Revised) Draft No. 6, supra note 14, $\$ 431(1)$. Comment d illustrates the point with examples based on U.S. re-export regulations. The comment states that "it might be reasonable for the United States to suspend the export privileges of a foreign firm that had knowingly re-exported a strategic product of U.S. origin to a target nation in violation of a prohibition, but that "it normally would be unreasonable" for the United States to deny the export privileges of such a firm solely because it traded with the target nation "in the absence of evidence that such trade involved goods of U.S. origin," since the United States would lack jurisdiction to prescribe with respect to such transactions. Id. $\$ 431$ (1) comment d. See also infra note 167. 
The principal argument in opposition to the position of the United States on restrictive conditions seems to be that even explicit private agreements cannot confer jurisdiction upon a state to prescribe legal rules outside its territory when international law does not confer it. ${ }^{161}$ While this may well be correct, ${ }^{162}$ the United States can respond that it is not prescribing law outside its territory. Rather, it is imposing conditions within its territory, and when those conditions are violated, it is suspending the ability of the purchaser to participate in further exports from the United States or imposing other penalties. In all instances, the United States is acting territorially. (Once again, however, the actions of the United States have sometimes extended beyond their rationale. In the 1959 Raytheon case approved by the Restatement, ${ }^{163}$ for example, the order suspending export privileges purported to prohibit all persons or firms, "whether in the United States or elsewhere," from doing business with the British firms penalized for violating re-export controls. ${ }^{164}$ The scope of denial orders like this should be limited in a manner consistent with the territorial rationale and other appropriate bases of jurisdiction.)

It might be noted, incidentally, that in other contexts governments are permitted to establish restrictions on conduct in the form of conditions on the receipt of benefits that they could not impose directly. Congress, for example, can impose conditions on individuals, private organizations, or states that receive funds appropriated under its spending power, even though it might not be empowered to legislate such rules directly (under its commerce power, for example). ${ }^{165}$

Consider finally the largely rhetorical point that the United States could, if it wished, direct its citizens and other residents of its territory not to do business with any foreign firm that traded with designated target nations. Such a secondary boycott would raise other issues, ${ }^{166}$ but it would appear to be valid as a matter of prescriptive jurisdiction under the territorial principle. ${ }^{167}$ If that is so, imposing conditions territorially on the purchase of

161. See EC Comments, supra note 5, at 895-96 ("The existence of ... submission clauses in certain private contracts cannot serve as basis for U.S. regulatory jurisdiction which can properly be exercised solely in conformity with international law."). See also Lowe, supra note 3, at 519-30.

162. See Note, Extraterritorial Application of the Export Administration Act, supra note 3, at 1325-26

163. See Restatement (Revised) Draft No. 6, supra note $14, \$ 431$ reporters' note 3.

164. See Raytheon Manufacturing Co., 24 Fed. Reg. 2626, 2627 (1959).

165. See L. Tribe, American Constitutional Law 247-50 (1978). Such conditions may not, however, violate the fundamental constitutional rights of individual citizens. See Feldman, supra note 8 , at 274-75.

166. The United States has refrained, except in wartime, from imposing secondary boycotts, Steiner, supra note 102, at 1368, and forbids U.S. persons acting in interstate or foreign commerce from complying with foreign secondary boycotts aimed at friendly states. 50 U.S.C. $\$ 2407$ (1979).

167. A comment in the Restatement (Revised) suggests that it would be unreasonable for the United States to deny export privileges to a foreign firm, as an exercise of enforcement jurisdiction, solely because that firm had traded with a target nation, since the United States would not have had jurisdiction to prescribe rules restricting such trade in the first instance. Restatement (Revised) Draft No. 6, supra note 14, $\$ 431$ comment d. See also supra note 160 and accompanying text. If the United States wished to implement a secondary boycott in the manner described, however, it could argue with some force, under much the same territoriality analysis applied earlier to re-export 
U.S. resources and enforcing them territorially by denials of U.S. export privileges-the penalty most commonly employed-should be no more troublesome.

When resources are mobile, in sum, the concepts of nationality and territoriality can readily accomodate regulation by the state of origin as well as the state of current location. Subtle questions remain about the extent to which a state may do indirectly what it arguably may not do directly, such as imposing conditions on exports or addressing regulations to parent corporations or the national officers and directors of foreign subsidiaries. ${ }^{168}$ The Restatement's "reasonableness" principle may be relevant to these questions, ${ }^{169}$ but it is unlikely to resolve them as a matter of principle. ${ }^{170}$

Space does not permit a full discussion of the "constitutional" rules of international law, such as sovereign equality, that Europe might invoke in support of its position. ${ }^{171}$ These rules would be central under the liberal dictum of the Lotus case ${ }^{172}$ or Mann's flexible test of jurisdiction, ${ }^{173}$ and they are also relevant under the Restatement scheme of territoriality and nationality. Like the principle of "reasonableness," however, these rules are too imprecise to resolve a controversy characterized by divergent national interests and widely differing perceptions of the relevant political and economic facts. Consider just one example, the principle of non-interference cited by the European Community in its 1982 comments on the pipeline regulations. ${ }^{174}$

The most complete statement of the non-interference principle, one with a "specific economic focus," 175 is found in the 1970 General Assembly Declaration on Principles of International Law Governing Friendly Relations and Cooperation Among States in Accordance with the Charter of the United

controls, see supra text accompanying notes 161-62, that it was not prescribing rules for foreign firms at all, but simply regulating with whom persons in the United States may trade, based in part on the relations of foreign firms with target nations.

168. Doing indirectly what may not be done directly is the essence of Lowe's criticism of the argument for re-export-type controls based on the consent of the purchaser. In Lowe's analytical scheme, public law must be separated from private law (a distinction not as such recognized in American law). Public law should not extend, should not even be given effect, beyond the territory of the enacting state, if it affects the public order of any other state. This is a nearly pure version of the territorial principle. "Submission clauses" contravene the territorial scheme; they are "the saddle for public laws to ride on the backs of private contracts." Lowe, Public International Law and the Conflict of Laws, supra note 3, at 525. See also Lowe, The Problems of Extraterritorial Jurisdiction: Economic Sovereignty and the Search for a Solution, 34 INT'L \& CoMP. L. Q. 724, 735-36 (1985).

169. See Restatement (Revised) Draft No. 7, supra note 11, §403.

170. Section 403, while requiring that any national regulation must reach some threshold of reasonableness, clearly recognizes the possibility of concurrent jurisdiction. See Maier, Resolving Extraterritorial Conflicts, or "There and Back Again," 25 VA. J. INT'L L. 7 (1984).

171. See supra note 116 and accompanying text.

172. See Bridge, supra note 3 , at $\mathbf{8 - 9}$.

173. See supra notes $132-42$ and accompanying text.

174. See EC Comments, supra note 5, at 895 ("The [effect of U.S. pipeline regulations] is an unacceptable interference in the affairs of the European Community.").

175. See Bridge, supra note 3 , at 9. 
Nations. ${ }^{176}$ That document "solemnly proclaims," inter alia, that no state has a right to intervene, directly or indirectly, in the internal or external affairs of another state; and, more specifically, that no state may use economic measures to coerce another state into subordinating the exercise of its sovereign rights or to obtain from it any kind of advantage. ${ }^{177}$ The Declaration also provides that every state has the right to choose its political and economic systems without interference in any form by other states. ${ }^{178}$ One can easily see how Europe, ${ }^{179}$ which views such extraterritorial controls as coercion, ${ }^{180}$ and the commentators supporting it, ${ }^{181}$ might eagerly embrace these provisions. They certainly lend weight to the European position.

Yet the United States can reasonably respond that, on a fair reading, the Declaration does not prohibit the kinds of extraterritorial regulation it employs as part of its trade control programs. First, the United States is not attempting to coerce other states into any subordination of their rights. It has largely given up the direct efforts at coercion represented by the Battle Act, and has almost never, in peacetime, tried to coerce foreign firms through a secondary boycott. States affected by extraterritorial regulation, moreover, retain all significant rights, including the right to block American controls. ${ }^{182}$

Second, U.S. controls do not in any significant sense interfere with the ability of other states to choose their political or economic systems, even though they may interfere with particular transactions. Indeed, the states most affected by American controls have largely market-oriented economic systems, with wide latitude for action by individual firms. It is quite consistent with such systems for firms voluntarily to agree to restrictive conditions in order to purchase U.S. resources.

Admittedly, the Declaration's provisions on non-interference could be read much more broadly than this. Overly broad readings, however, tend to prove too much: At the extreme, they would prohibit any action that produced negative externalities for other states, and this is clearly not the nature of current international relations. ${ }^{183}$

Even more fundmentally, the very principle of non-interference is deeply ambiguous in a way that limits its relevance to the extraterritoriality controversy. It is the essence of the "functionally associated resources"

176. See Declaration on Principles of International Law Concerning Friendly Relations, GA Res. 2625, 25 U.N. GAOR Supp. (No. 28) at 121, U.N. Doc. A/8028 (1971) (adopted, without vote, Oct. 24, 1970), reprinted in 9 INT'L Legal Materials 1292 (1970).

177. Id.

178. Id.

179. See EC Comments, supra note 5, at 893, 895 .

180. See supra text accompanying notes $111-17$.

181. See Bridge, supra note 3, at 9-10, 16-17; Lowe, supra note 3, at 522-23; Lowe, The Problems of Extraterritorial Jurisdiction, supra note 168 , at 740-43.

182. This is reminiscent of Professor Weil's position that international law permits states to engage in extraterritorial regulation, but also permits affected states to refuse to give effect to such regulation. See supra text accompanying notes 125-26.

183. See Farer, Political and Economic Coercion in Contemporany Imtemational Law, 79 AM. J. INT'L L. 405,406 (1985) ("As a legal proposition, such language is perfectly empty; for if read literally, it would outlaw diplomacy."). 
rationale underlying U.S. controls that the regulation of important resources is not always the "affair" solely of the state where those resources are located at any point in time. In appropriate cases, it may also be the "affair" of the state of origin. Allocating the "affairs" associated with mobile resources and multinational enterprises among the interested territorial states is essentially a political decision. Until it is made, the principle of non-interference will remain only a form of words.

\section{VI \\ Recent Developments and the OUtlook for the Future}

Perhaps the most significant fact to emerge from the pipeline episode is that, at the end of the day, Europe has the physical power-supported in most cases by the territorial principle ${ }^{184}$ - to block extraterritorial controls that are costly or intrusive enough to make such action worthwhile. The United States might see many blocking actions as unfair, ${ }^{185}$ but it is almost unthinkable that it would attempt physically to halt foreign transactions it had attempted to control. To do so would violate what the Lotus case called the "first and foremost restriction imposed by international law."186 The United States generally respects the superior power of the territorial state, and recognizes the fruitlessness of penalizing the private firms caught in the middle, by the principle of sovereign compulsion. ${ }^{187}$ Thus, the likelihood of another costly confrontation like that of 1982 may be sufficient to convince the United States to moderate the exercise of its claims.

Considerable moderation can already be observed. Perhaps most noteworthy, the several trade controls imposed by the United States since 1982 have been limited in their extraterritorial effects. The best example is the embargo of Libya instituted in 1986 under the International Emergency Economic Powers Act ("IEEPA") and special legislation, ${ }^{188}$ building on a

184. See Restatement (Revised) Draft No. 6, supra note $14, \S 436(2)$ comment b.

185. As noted above, supra text accompanying note 97 , foreign firms may pay reduced prices for goods or technology purchased subject to restrictive conditions, in which case the states of the purchasers can be seen as giving up fewer resources in exchange for the resources its firms acquire from the United States. Foreign government orders requiring completion of transactions utilizing those resources, in the face of U.S. restrictions, can thus be seen as allowing both the firms and the states themselves to reap unbargained-for advantages.

186. See supra note 120.

187. See Restatement (Revised) Draft No. 6, supra note 14, $\$ 436(1)$. The United States deviated from this principle briefly during the pipeline confrontation, see supra note 31 and accompanying text, in part on the ground that the foreign firms involved had worked to procure the compulsion. See Moyer \& Mabry, supra note 2, at 71-73: Memorandum of Points and Authorities in Opposition to Plaintiffs' Motion for a Preliminary Injunction, at 30-38; Dresser Indus., Inc. v. Baldrige, No. 82-2385 (D.C.C. 1982)

188. See International Emergency Economic Powers Act. 50 U.S.C. $\$ \$ 1701-1706$ (1982); International Security and Development Cooperation Act of 1985 , tit. V, $\$ 504$, Pub. L. No. 99-83, 99 Stat. 221, (codified at 22 U.S.C. $\$ 2349$ aa-8 (Supp. III 1985)); Exec. Order No. 12,543, 51 Fed. Reg. 865 (1986); Libyan Sanctions Regulations, 51 Fed. Reg. 1354, 2462 (1986); Exec. Order No. 12,544, 51 Fed. Reg. 1253 (1986); Restrictions on Exports Involving Libya, 51 Fed. Reg. 2353 (1986); see also Bialos \& Juster, The Libyan Sanctions: A Rational Response to State-Sponsored Terrorism, 26 VA. J. INT'L L. 799 (1986). 
partial trade embargo imposed in $1982 .{ }^{189}$ The 1982 regulations required validated licenses or similar authorizations for exports and re-exports to Libya of most U.S.-origin commodities and technical data and for foreign exports of goods incorporating U.S.-origin parts, components, or materials. ${ }^{190}$ They also required licenses for foreign exports of locally-made products of U.S.origin technology, but this restriction applied only to items controlled for national security purposes, only to prospective transactions, and only in cases where written assurances had been given. ${ }^{191}$ The stated licensing policy was to approve most controlled exports and re-exports, except those items which were controlled for national security purposes or related to oil and gas, and which were not readily available outside the United States. ${ }^{192}$ Even with such items, licenses would generally be issued, or at least favorably considered, in re-export cases involving goods or technology exported before the embargo or sales under preexisting contracts, and in parts and components cases where the U.S.-origin content comprised twenty percent or less of the value. ${ }^{193}$

The 1986 regulations tightened these controls, but did not greatly extend their extraterritorial reach. The new rules instituted a more complete embargo on exports, but this was limited mainly to exports "from the United States." 194 They prohibited "U.S. persons" from performing most contracts in support of projects in Libya ${ }^{195}$ and from engaging in certain extraterritorial trade transactions, such as the purchase of Libyan goods for export to another country. ${ }^{196}$ "U.S. persons" were defined, however, not to include foreign

189. 47 Fed. Reg. 11, 247 (1982). The 1982 embargo expanded on earlier export controls imposed for national security, antiterrorism and regional stability purposes. Id.

190. See 15 C.F.R. $\$ 385.7$ (a)(1985).

191. See id.

192. See id. Licenses would also generally be denied for exports of goods and technical data for the Ras Lanuf petrochemical plant.

193. See id. $\$ 385.7(\mathrm{a})(2)$.

194. See 51 Fed. Reg. 1354 (1986) (to be codified at 31 C.F.R. $\$ 550.202$ ). These new regulations provided no exception for prior contractual commitments.

As originally promulgated, the embargo regulations prohibited exports from the United States to a third country if the exporter had reason to believe that the goods would be transshipped to Libya without being incorporated into manufactured products or otherwise "substantially transformed", but permitted them if the exporter had reasonable cause to believe that the goods would be substantially transformed or would come to rest in the third country, as by inclusion in inventory, before shipment to Libya. See id. at $\$ 550.409$. This regulation was later amended to prohibit exports to third countries whenever the exporter knows or has reason to know either (1) that the exported goods or technology are to be transshipped without coming to rest and being substantially transformed or incorporated into manufactured goods, or (2) that the exported goods or technology are intended specifically for substantial transformation or incorporation into products to be used in the Libyan petroleum or petrochemical industries. See 51 Fed. Reg. 22,802 (1986) (amending 31 C.F.R. \$550.409).

195. See 31 C.F.R. $\$ 550.205$ (1986).

196. See id. at $\S 550.204$. The prohibition on performance of contracts "in support of" Libyan projects, id. \$550.205, could be interpreted to prevent "U.S. persons" from participating in the export to Libya from third countries of goods or technology destined for such projects. Individual U.S. persons employed by foreign firms, including foreign subsidiaries of American firms, are subject to this prohibition. See Ellicott, The New U.S. Embargo on Trade and Financial Dealings uith Libya, 2 INT'L Bus. \& Trade ReP. 17, 18-19 (1986). 
subsidiaries or other affiliates. ${ }^{197}$ Foreign branches-but not subsidiaries-of American banks were made subject to the regulations freezing Libyan government assets, ${ }^{198}$ but the freeze was limited to dollar-denominated assets. ${ }^{199}$ While the Libya embargo involves an extensive set of economic sanctions, then, ${ }^{200}$ it does not have anything like the sweeping extraterritorial reach of the 1982 pipeline controls, in spite of the prominent place occupied by Libya in American foreign policy during 1986. Foreign subsidiaries are not restricted as such, and while many re-export-type transactions require a license, little third-country trade with Libya is actually embargoed. ${ }^{201}$

The 1985 IEEPA embargo of Nicaragua-another country prominent in U.S. foreign policy-is even more restrained. It covers only exports "from the United States either to or destined for Nicaragua," and thus does not include even re-export controls. ${ }^{202}$

In March 1987, the Reagan Administration relaxed U.S. controls on foreign exports of manufactured products incorporating U.S.-origin parts, components, or materials. ${ }^{203}$ Under the revised rule, such exports to certain specified destinations will be permitted without prior authorization if the value of the U.S. content is twenty-five percent or less of the value of the goods; they will be permitted to any destination if the value of the U.S. content is both ten percent or less of the value of the goods and equal to $\$ 10,000$ or less. ${ }^{204}$

This sort of de minimis exception has already been successfully applied, almost always as a matter of licensing policy, notably in the embargoes of

197. See 31 C.F.R. $\$ 550.308$ (1986). Transactions involving a foreign subsidiary could in some circumstances run afoul of the prohibition on transactions undertaken with the purpose or effect of evading any of the embargo regulations. Id. at $\$ 550.208$. See Ellicott, supra note 196, at 17-18. In July 1986, the Treasury Department imposed a reporting requirement on U.S. firms with foreign affiliates engaging in transactions with Libya, designed to monitor compliance with the anti-evasion rule. See 51 Fed. Reg. 25,634 (1986).

198. See Exec. Order No. 12,544 (1986); 31 C.F.R. $\$ 550.209$ (1986) (added by 51 Fed. Reg. 2462 (1986)).

199. See 31 C.F.R. $\$ 550.516$ (1986) (added by 51 Fed. Reg. 2462, 2466 (1986)).

200. Also included are restrictions on imports from Libya, 31 C.F.R. $\$ \$ 550.201, .407-.408$ (1986), and travel to Libya, 31 C.F.R. $\$ 550.207$ (1986).

201. See Ellicott, supra note 196, at 20.

202. See Exec. Order No. 12,513, 50 Fed. Reg. 18,629 (1985); Nicaraguan Trade Control Regulations, 31 C.F.R. Pt. 540 (1986). The export prohibition is set out in 31 C.F.R. $\$ 540.205$ (1986); see also 31 C.F.R. \$ 540.401(b) (1986). Exports to third countries are prohibited where the exporter has reasonable cause to believe that the goods will be incorporated into manufactured products or otherwise substantially transformed before shipment to Nicaragua. See id. $\$ 540.406$.

203. 52 Fed. Reg. 9147 (1987).

204. Id. at $9147-50$ (amending 15 C.F.R. $\$ 376.12$ (1987)). Such exports will also be permitted if the U.S. content in a single unit is of very low dollar value, if the U.S. content could be exported under certain general licenses, or if the foreign exports meet any of the conditions for permissive reexports in 15 C.F.R. $\$ 374.2$ (1987). Id.

The value of the U.S. content is to be the delivered price to the foreign manufacturer, except that fair market prices are to be substituted in sales between affiliated firms made at below normal prices. The value of the foreign product is to be the normal export price FOB factory. Id.

The destinations for which the twenty-five percent limit is applicable are, with certain stated exceptions, those listed in Supplements 2 and 3 to 15 C.F.R. Pt. 373 (1987).

Exports of foreign-manufactured supercomputers utilizing U.S.-origin components will continue to require prior authorization. Id. 
Cuba and Libya. ${ }^{205}$ Its inclusion in the general export administration regulations, applicable even to items controlled for national security reasons, represents an important change of direction for U.S. policy. The revised rule does appear, however, to authorize a form of retroactive regulation: A country could seemingly be removed from the list of approved destinations after parts have been exported from the United States, subjecting exports of the foreign-produced end product to the ten percent $\$ 10,000$ limit, rather than the more lenient twenty-five percent test. ${ }^{206}$

Within the Executive branch, the Department of State has worked to develop a procedure for reviewing actions proposed by other government agencies that would have extraterritorial application or might otherwise affect foreign interests. Under that procedure, executive agencies must inform the Department of State of any such proposed action and consult with it if appropriate. This procedure is intended to help the government "manage" the extraterritoriality problem by continuing to moderate the foreign effects of its actions where the national interest permits. ${ }^{207}$

This internal process is linked to an external commitment to moderation negotiated in 1984, within the framework of the Organization For Economic Cooperation and Development (OECD). Since 1976, the OECD Guidelines for Multinational Enterprises" 208 have addressed the problem of "conflicting requirements" imposed upon multinational enterprises by member countries, including the regulation of foreign subsidiaries and affiliates by the government of the parent's home country in conflict with the law or policy of the state where the affiliate operates. ${ }^{209}$ During the 1984 review of the Guidelines, the United States joined with other OECD countries in issuing a statement designed to strengthen international cooperation and avoid or limit the scope of conflicting requirements. ${ }^{210}$ The statement provides that, in

205. For a discussion of de minimis exceptions, see Abbott, supra note 1, at 133-34.

206. See 52 Fed. Reg. 9147, 9149-50 (1987) (amending 15 C.F.R. \$ 376.12(a)). Section 376.12(a)(1) requires prior authorization for exports from foreign countries of products incorporating U.S.-origin components, and most of the exceptions in the revised rule are explicitly to be applied as of "the time of export of the foreign-made product to the new country of destination." See 15 C.F.R. $\$ 376.12$ (a)(1)-(2) (1987). Unfortunately for the clarity of the revised rule, the quoted phrase is not included in the paragraph establishing the twenty-five percent and ten percent $\$ 10,000$ U.S. content exceptions, see id. $\$ 376.12(\mathrm{a})(3)$, but the sense of that paragraph appears to be the same.

207. See Dam, Extraterritoriality, Conflicts of Jurisdiction, and United State Foreign Policy, supra note 4, at 21-22; Shultz, Trade, Interdependence, and Conflicts of Jurisdiction, supra note 4, at 36; Small, supra note 122 , at 290,301 .

208. See The Guidelines for Multinational Enterprises, Annexed to the Declaration of 21st June 1976 by Governments of OECD Member Countries on International Investment and Multinational Enterprises, as amended, reprinted in The OECD GuIdelines FOR MULTINational ENTERPRises 16 (1986) [hereinafter Guidelines]. See also Second Revised Decision of the Council on the Guidelines for Multinational Enterprises, reprinted in OECD, THE OECD Guidelines fOR Multinational ENTERPrises $71-72$ (1986) [hereinafter Decision].

209. See Guidelines, supra note 208, at 11; Decision, supra note 208, at 7-9.

210. See Section on Conflicting Requirements, Endorsed by Ministers on 17th May 1984, from the Report by the Committee on International Investment and Multinational Enterprises on the $198+$ Review of the OECD 1976 Declaration on International Investment and Multinational Enterprises, reprinted in OECD, THE OECD Guidelines for Multinational ENTERPRises 75-76 (1986). 
contemplating exercises of jurisdiction which may conflict with the laws or policies of another member state, OECD countries should: (1) have regard to relevant principles of international law; (2) endeavor to avoid or minimize conflicts through an approach of "moderation and restraint"; (3) take into account the sovereignty and legitimate interests of other member countries; and - of special interest after the pipeline case-(4) bear in mind the importance of contractual obligations and the adverse impact of retroactive measures. The statement also urges cooperative action as an alternative to unilateral measures that may create conflicts, and includes a set of "practical approaches" designed to stimulate notification and consultation. ${ }^{211}$

This statement is precatory on two levels: (1) it does not require states to do anything, but only sets forth what they "should" do in particular situations; and (2) the actions it urges states to take are only to "consider," "endeavor," "take into account," and the like. The statement refers to international law, but does not characterize its content. It also relies heavily on consultation, which will be of limited value when states hold deeply different interpretations of a factual situation. It does, however, express a political commitment to restraint, and that constitutes considerable progress so soon after the pipeline confrontation.

Congress contributed to the climate of moderation by addressing the problem of retroactivity in a 1985 amendment to the EAA. Under this amendment, no foreign policy export control may prohibit either an export or a re-export of goods or technology that is to be made pursuant to a preexisting contract, or to any validated license or authorization under the EAA. ${ }^{212}$ This "contract sanctity" clause is aimed primarily at protecting American exporters. ${ }^{213}$ By limiting the retroactivity of re-export controls, however, it deals with one of the major irritants of the pipeline episode. ${ }^{214}$ Contracts can only be "desanctified" under the amendment if the President certifies the existence of a "breach of the peace" that poses a "serious and direct threat to the strategic interests of the United States."'215

All of this may suggest that the United States has learned a great deal from the pipeline episode, and perhaps even that the longstanding controversy

211. See id. at 5-6.

212. Export Administration Amendments Act of 1985, supra note 9, $\S 108$ (1) (amending EAA $\$ 6$ to add paragraph (m), "Effect on Existing Contracts and Licenses").

213. For a discussion of contract sanctity clauses, including the legislative proposals leading up to the $1985 \mathrm{Act}$, see Abbott, supra note 1, at 130-33.

214. The amendment does not deal expressly with retroactive controls on exports of products of U.S.-origin technology, the most controversial aspect of the pipeline regulations. Presumably, however, such controls would affect "the export . . . of goods"-by the foreign holder of the technology-within the meaning of the statute.

215. Export Administration Amendments Act of 1985, supra note 9, $\S 108(1)$. The President must also certify that the interruption of contracts or licenses will be instrumental in remedying the situation posing the threat, and that the controls will continue only so long as the threat persists. Id. This appears to have been intended as a fairly narrow exception, but in fact most of the trade controls of recent years-like those responding to the Soviet invasion of Afghanistan, the seizure of hostages in Iran, and the support of terrorists by Libya-could be said to fall within the quoted language. 
over extraterritorial trade controls has at last been resolved. The first of these conclusions is probably accurate; the second, however, would be excessively optimistic. The more closely one examines the post-1982 evidence of moderation, the "softer" it appears. Moderate trade controls can become more extensive if they prove ineffective, as in 1982; the State Department can be overriden; the OECD statement is too general to act as a real restraint; the contract sanctity amendment to the EAA still permits some retroactive controls, including any control said to be imposed for national security purposes; and the Libya and Nicaragua embargoes serve as a reminder that the IEEPA, which contains no contract sanctity clause, can also be used as an authority for political trade controls.

The Reagan Administration's approach has been to moderate the exercise of extraterritorial jurisdiction, out of comity or concern for U.S. commercial interests, in particular situations, without yielding any of its jurisdictional claims. $^{216}$ Congress, for its part, has done little to limit extraterritorial regulation, in spite of the strong representations made by European governments. Given the consistent American claims of extraterritorial jurisdiction over the past thirty years, this reluctance to change course dramatically should not be surprising. It means that, instead of a period free of controversy, there may lie ahead a period of continued debate and uncertainty, with the potential for periodic conflicts, until a true resolution finally emerges.

\section{VII}

\section{Conclusion: A Negotiated Solution}

In an earlier article ${ }^{217}$ I recommended that the United States and Europe try to avoid the period of uncertainty and conflict just described by directly negotiating the permissible extraterritorial reach of national trade controls in particular situations. ${ }^{218}$ This approach is still the most desirable. Recent developments suggest, however, that the earlier article may have been too sanguine about the prospects for success.

In spite of many brave words to the effect that the West "cannot afford a repetition of the pipeline fiasco, a fiasco that damaged the Western alliance far more than it hurt the Russians," 219 the only negotiated result since 1982 has been the OECD statement described in the preceding section. The two sides have brought quite different attitudes to the negotiations that have taken

216. See Dam, Extraterritoriality, Conficts of Jurisdiction, and Linited States Foreign Policy, supra note 4, at 21-22; Shultz, Trade, Interdependence, and Conflicts of Jurisdiction, supra note 4, at 36; Small, supra, note 122 , at 301 . The new parts and components regulation was expressly presented as a way to "reduce the disincentive to use U.S.-origin parts and components in foreign manufactures." 52 Fed. Reg. 9147,9148 (1987).

217. See Abbott, supra note 1.

218. For another argument in favor of compromise, suggesting regulation of re-export-type controls through a "rule of reason," to be implemented through bilateral or multilateral consultations, see Feldman, supra note 8, at 274-79.

219. See Havers, Good Fences Make Good Neighbors, supra note 4, at 24. 
place: Europe, especially the British, wishes to discuss abstract principles of jurisdiction, while the United States favors the discussion of practical solutions. ${ }^{220}$ These attitudes may reflect not only differing national traditions, but also the very different interpretations of the relevant facts the two sides bring to the table. ${ }^{221}$

In addition, both sides have practical reasons-beyond the reasons of principle discussed in this article-for being reluctant to compromise. Europe presumably feels some confidence in its ability to block American controls. The United States accepts the possibility of blocking, but knows that foreign governments will attempt it only in extreme situations. ${ }^{222}$ Europe may well believe that resistance to American investment abroad in sensitive sectors, avoidance of U.S.-origin components, and weakening of the national treatment principle-among other responses to extraterritorial jurisdictionwill force the United States to retract its claims without negotiations. ${ }^{223}$ For its part, the United States is reluctant to restrict its freedom of action in the intertwined areas of national security and foreign policy because of the "primacy of security, its competitive nature, the unforgiving nature of the arena, and the uncertainty of how much security the state needs and has. ...'224 Even in the area of pure foreign policy, the United States uses economic sanctions to communicate its commitments and intentions, and it may use extraterritorial controls to signal that it views a given situation as meriting an extraordinary response; rules limiting extraterritorial reach would interfere with this function. ${ }^{225}$

In spite of these difficulties, however, there exist important reasons for pursuing a negotiated solution. As this article has attempted to demonstrate, both the United States and Europe have valid interests at stake in the controversy. The interests of the United States include maintaining some control over its resources, and resources associated with it, in order to maximize its power and limit free-riding by other states as well as its own multinationals. Europe's interests include resisting foreign coercion over the use of resources that have entered its economy. Both Europe and the United States, moreover, have at least arguably valid legal claims. Out of comity, ${ }^{226}$ mutual respect, concern for the Western alliance, ${ }^{227}$ and respect for the

220. See Small, supra note 122, at 288, 291.

221. See suprn text accompanying notes 59-72, $111-15$.

222. The United States currently maintains, after all, both potentially retroactive re-export controls, 15 C.F.R. $\$ \S 371,1,374.2(\mathrm{a}), 379.9$ (b) (1985) ("at the time of re-export"), and controls on exports by foreign subsidiaries, 31 C.F.R. $\$ \S 500.201,500.329$ (1985) (one of many examples), without foreign interference.

223. See Shultz, Trade, Interdependence, and Conficts of Jurisdiction, supra note 4, at 35 (such responses make it "imperative" to "manage the problems of conflicts of jurisdiction").

224. Jervis, Security Regimes, 36 InT'L OrG. 357, 359 (1982).

225. See D. Baldwin, Economic Statecraft 243 (1985).

226. The State Department views comity - something "between pure discretion and hard law" as the principle by which problems of concurrent jurisdiction should be resolved. See Small, supra note 122 , at 291 .

227. See, e.g., North Atlantic Treaty, Apr. 4, 1949, art. 2, 63 Stat. 2241, 2242, T.I.A.S. No. 1964, 34 U.N.T.S. $243,244,246$ (parties commit to eliminate conflict in international economic policies). 
principle of peaceful settlement of disputes, ${ }^{228}$ these divergent positions should be reconciled by negotiation, not through near-hostilities like those of 1982 or the application of political and economic pressure.

Second, a period of uncertainty and occasional controversy like that forecast above would be inefficient and wasteful for both sides. International transactions would have to proceed subject to ambiguity and risk, increasing the cost of doing business; international trade, technology transfer, and investment would be distorted in anticipation of possible extraterritorial controls and foreign responses, even when no such controls were in effect; and political capital would be expended in controversy. Continued dispute could "interfere seriously with the smooth functioning of international economic relations."229

Third, it may be important to reach a firm, long-term resolution of at least some parts of the extraterritoriality problem during the current period of moderation. Most government officials have short time horizons; because they or their superiors must regularly be reelected, far-off events and consequences are heavily discounted relative to those in the near future. Future American governments may thus be tempted to try for short-run foreign policy (or domestic political) gains by imposing extensive extraterritorial controls, in spite of the longer term adverse consequences, both political and economic, to the country. International rules and agreements are often used to forestall such self-defeating actions by binding successor governments, and the time seems ripe to apply this strategy to extraterritorial trade controls. ${ }^{230}$

Finally, as pointed out in an earlier article, ${ }^{231}$ there exist a number of compromise formulations, drawn from various functioning trade control programs, that could allocate jurisdiction over common transactions in ways that would respond to the interests of the United States and Europe, provide increased clarity for international traders, and minimize the possibility of costly international confrontations. The availability of these formulations could give a running start to negotiations. As these formulations have been illuminated elsewhere in more detail, the following are only a few brief examples:

(1) At the least, whatever types of controls were permitted under a negotiated regime should extend only so far as is consistent with their supporting rationales. In particular, re-export-type controls should only be permitted to the extent the conditions the United States purports to impose on exports are clearly spelled out in advance and communicated

228. See, U.N. Charter art. 2, para. 3; North Atlantic Treaty, Apr. 4, 1949, art. 1, 63 Stat. 2241 , 2242, T.I.A.S. No. 1964, 34 U.N.T.S. 243, 244; Declaration on Principles of International Law Concerning Friendly Relations, supra note 176.

229. See Shultz, Trade, Interdependence, and Conflicts of Jurisdiction, supra note 4, at 33, 35.

230. For a discussion of the short time horizon problem and the use of international rules to avoid self-defeating actions, in the context of protectionist acts, see Abbott, The Trading . Tation's Dilemma: The Functions of the Law of International Trade, 26 HARv. INT'L L.J. 501, 521 (1985).

231. See Abbott, supra note 1, at 120-57. 
to prospective purchasers. ${ }^{232}$ The United States might be well advised to amend its export control regulations in this way unilaterally, to clean its hands and strengthen its rationale, whether for negotiations or for controversy.

(2) Prospective re-export-type controls might be permitted, retroactive ones prohibited. ${ }^{233}$ Even though the rationale of imposing conditions on exports from U.S. territory logically supports retroactive controls, ${ }^{234}$ they are unpredictable and intrusive, coming into effect after goods or technology have entered a foreign economy, and are likely to provoke foreign blocking actions. The contract sanctity amendment to the EAA constitutes a significant step toward this position, ${ }^{235}$ and even before that legislation was adopted the Reagan Administration had indicated its intention to avoid retroactive controls. ${ }^{236}$ A prohibition in the form of an international obligation, though, might satisfy Europe more. The form of a negotiated prohibition, moreover, would likely be different from one unilaterally adopted.

(3) The recent de minimis exception for foreign sales of goods incorporating U.S.-origin parts, components and materials, ${ }^{237}$ could serve as a basis ${ }^{238}$ for a general negotiated limit on that form of re-export control. ${ }^{239}$

(4) Even prospective re-export-type controls could be required to terminate at the point, to be defined, at which U.S.-origin goods and technology have "come to rest" in a foreign economy. Such a requirement would reflect an agreement that the predominant "functional associations" switch at that point from the state of origin to the destination state. ${ }^{240}$ This "coming to rest" concept was incorporated, in a slightly different context, in the Libyan embargo regulations. ${ }^{241}$

(5) Foreign firms, both affiliates and independent firms, might be subject to U.S. regulation when they participate in the "evasion" of territorial American controls-a formulation that reflects U.S. concern with free-riding-but not when they participate in bona fide transactions. ${ }^{242}$ The kinds of transactions that would constitute "evasion" would have to be clearly defined, or else the term could

232. See supra text accompanying notes 98-100.

233. See Abbott, supra note 1, at 138-41.

234. See supra text accompanying note 96 .

235. See supra text accompanying notes 212-15.

236. See Dam, Extraterritoriality, Conficts of Jurisdiction, and L'mited States Foreign Policy, supra note 4, at 18-19. The force of this statement is weakened by its connection to the administration's contract sanctity proposal, which would have protected only those contracts under which performance was to be completed within $\mathbf{2 7 0}$ days after the imposition of a control. See id.

237. See supra text accompanying notes 203-04.

238. David Small has suggested that a U.S.-content threshold as high as fifty percent might be necessary to obtain European acquiescence. See Small, supra note 122, at 300.

239. For a discussion of de minimis rules, see Abbott, supra note 1, at 133-34.

240. See id. at 134-37.

241. See 51 Fed. Reg. 1354 (1986) (adding 31 C.F.R. $\$ 550.409$ (a)(2) and amended by 51 Fed.

Reg. 22,802 (1986)). See also supra note 189.

242. For a discussion of evasion rules, see Abbott, supra note 1, at 123-30. 
become a loophole for extensive American regulation and a new source of controversy. The anti-boycott regulations adopted under section 8 of the $\mathrm{EAA}^{243}$ provide a basis, but only a basis, for a workable definition. An anti-evasion provision was added to the foreign policy section of the EAA in $1985,{ }^{244}$ and one was included in the Libya sanctions regulations. ${ }^{245}$ Yet for all the evident appeal of the evasion concept, there is little experience with the actual application of any of these rules, and one should proceed cautiously in relying solely on an evasion formulation.

(6) Foreign subsidiaries might be subject to U.S. regulation when they are acting at the direction or as agents of their American parents, but not when they are acting as independent foreign firms. ${ }^{246}$ This formulation responds directly to the United States' concern with free-riding by multinationals.

(7) U.S. controls could extend to foreign subsidiaries only to the extent those subsidiaries are engaged in U.S. commerce, as under the antiboycott statute, ${ }^{247}$ reflecting the fact that the resources involved in such transactions have multiple associations with the United States. ${ }^{248}$ In most cases, including the pipeline episode, the foreign subsidiaries reached by American regulations do have multiple economic associations with the United States, ${ }^{249}$ even though the regulations may, by their terms, require no other connection than ownership or control by U.S. persons. Under the principle of multiple connections used in the anti-boycott statute, however, those additional economic connections, such as the use of U.S.-origin goods or technology, would have to figure in the particular transactions subject to regulation.

Some of these limiting formulations could be unilaterally administered. The United States could simply refrain, for example, from imposing retroactive re-export controls. Many of them, however, might-if left to unilateral administration-serve only to create new subjects of controversy. As noted above, for example, an evasion rule could be interpreted by the United States so broadly as effectively to nullify a negotiated settlement. Even if the rule were applied in good faith, there might be disagreements about the existence of evasion. To deal with this kind of problem, a negotiated settlement should include several administrative provisions.

243. 50 U.S.C. $\S 2407$ (a)(5) (1982); 15 C.F.R. $\S 369.4$ (1985).

244. See Export Administration Amendments Act of 1985, § 108(a)(3) (adding new $\S 6(a)(2)$ ), 50 U.S.C. $\$ 2405$ (a)(2) (Supp. 1986).

245. See 31 C.F.R. $\$ 550.208$ (1986). The provision might extend the effective extraterritorial reach of the embargo. See Ellicott, supra note 191, at 17-18. The Treasury Department has instituted a reporting requirement designed to ensure compliance with the anti-evasion rule. See supra note 196.

246. For a discussion of agency rules, see Abbott, supra note 1, at 146-50.

247. See 50 U.S.C. $\$ 2407$ (a)(1) (1982) ("with respect to his activities in the interstate or foreign commerce of the United States").

248. For a discussion of the U.S. commerce rule, see Abbott, supra note 1, at 144-46.

249. See supra text accompanying notes 86-88. 
First, the European governments should agree to cooperate with the United States in gathering the information necessary to properly administer the agreed substantive rules. This should be the case whether the rules are based on evasion or on other flexible concepts like coming to rest, agency, or U.S. commerce, or whether they simply require information located abroad, such as the existence of prior contracts or the value of foreign goods incorporating U.S.-origin components. ${ }^{250}$ Second, the United States and the European governments should agree to consult as to the application of the agreed rules. Consultations might take place before a program of controls is instituted, and should certainly take place when the particular application of an agreed jurisdictional rule is challenged. Similar arrangements have been included in certain agreements relating to antitrust enforcement. ${ }^{251}$ Finally, an additional dispute settlement procedure, perhaps based on three-person panels, might be established to deal with disputed instances of regulation not resolved by consultation. While such a mechanism would probably be unacceptable in the current state of uncertainty, it could work well in connection with a set of agreed jurisdictional rules.

In addition, the European governments would be expected to promise not to interfere with permissible forms of American regulation, either by formal blocking actions or informal measures, and to follow the agreed jurisdictional principles in any extraterritorial regulation they might themselves promulgate in the future. ${ }^{252}$ Other concessions might also be obtained. ${ }^{253}$ This kind of agreement, coupled with consultations on the underlying political problems, should allow us to avoid another "pipeline fiasco."

250. See Abbott, supra note 1, at 152.

251. See id. at 121-23.

252. See id. at 151 .

253. See id. at 153-54. 